\title{
From Esoteric to Pure Land and Huayan Buddhism: Uṣṇiṣavijayā Dhāraṇi Mandala in Liao Buddhism
}

\author{
Youn-mi Kim
}

I. Introduction

II. Text and Image: Early Liao Mandala and Tang Scriptures

III. Three-dimensional Mandala

IV. Textual Mandala: Modification and Expansion

V. Conclusion

\section{Introduction}

The Uṣnịṣavijayā dhāraṇ̄ (Foding zunsheng tuoluoni 佛頂尊勝陀羅尼), known for its efficacy in removing bad karma and prolonging one's lifespan, was one of the key Buddhist incantations in premodern China. ${ }^{1}$ Once the incantation became widespread in the Tang dynasty (618-907), it began

1 The textual source of the uṣnịșavijayā dhārañi is the Sutra of the Uṣnịșavijayā dhäraṇi (Foding zunsheng tuoluoni jing 佛頂尊勝陀羅尼經). The sutra was so popular that it was translated five times in China, once each by Buddhapālita (T. 19, no.967), Du Xingyi (T. 19, no. 968), and Yijing (T. 19, no. 971), and twice by Divākara (T. 19, no. 969, and T. 19, no. 970). They have similar but slightly different contents. Among these, the translation by Buddhapālita was most widely used. For the political characteristics of the preface of Buddhapāita's translation, see Antonino Forte, "The Preface to the So-called Buddhapalita Chinese Version of the Buddhosnịna Vijaya Dhāraṇi Sütra" unpublished paper, quoted in Paul F. Copp, "Voice, Dust, 
to engender new types of material culture. Perhaps the best-known monument linked to this incantation was the jingchuang 經幢, or dhäraṇi pillar, that was erected for engravings of its text during the Tang. Such pillars proliferated throughout the Liao dynasty (907-1125). ${ }^{3}$ During the Liao period, however, another type of ritual object formed a main branch of the material culture pertaining to the Ușnissavijaya dhärañ - the mandala that was used for activating the power of this important incantation.

As this paper shows, the Ușniṣavijayā Dhäraṇi Mandala, consisting of the Eight Great Bodhisattvas with a Vairocana Buddha in the center, played a crucial role in Liao dhāraṇi practice. By exploring archaeological traces of the mandalas remaining in the representative pagodas from Liao, this paper elucidates how this mandala was understood, used, and modified in Liao Buddhist practice. Such an examination offers the rare opportunity to broaden our understanding of the evolution of the Ușnişavijaya a dhäraṇi practice in the late medieval period after its initial flourishing in the Tang. It also sheds new light on Liao esoteric Buddhism. Mandalas from Liao pagodas inform us that esoteric Buddhism in Liao was integrating Pure Land and Huayan Buddhism in practice by the late eleventh century. As this paper reveals, early Ușnișavijayā Dhäraṇi Mandalas from the mideleventh century showed fidelity to instructions in Tang scriptures translated by Amoghavajra (Bukong Jingang 不空金剛, 705-774), while exhibiting Liao characteristics only in details unrelated to the basic iconography. In the late eleventh century, however, the mandala transformed into a more complicated form and absorbed deities not only from esoteric Buddhism but Huayan and Pure Land Buddhism as well.

The Ușnịsavijayā Dhäraṇi Mandalas remaining in the Liao pagodas are valuable data to fill lacunae in the written documentation of Liao Buddhist practice. Few writings by Liao monks have survived. Some are included in the Newly Compiled Comprehensive Catalogue of Canonical Works of the Various Schools by the Koryo dynasty's prince-monk, Üich'ŏn 義天 (1055-1101). ${ }^{4}$ The catalogue informs us that Sixiao 思孝 (also known as Great Master Haishan 海山大師), one of the most eminent monks in Liao, wrote a commentary and exegesis on the mandala, but their contents are unknown because the catalogue only records their titles. Mandalas discussed in this paper help to deductively reconstruct his understanding of the Uṣnịșavijayā Dhäraṇī Mandala.

Shadow, Stone: The Makings of Spells in Medieval Chinese Buddhism," PhD dissertation (Princeton University, 2005), 46, footnote 78; Chen Jinhua, "Śarīra and Scepter: Empress Wu's Political Use of Buddhist Relics," Journal of the International Association of Buddhist Studies 25, no. 1-2. (2003): 33-150; and T. H. Barrett, "Stūpa, Sütra, and Sarīra in China, c. 656-706," Buddhist Studies Review 18, no. 1 (2001): 1-64. Barrett also discussed the role of the Ușnīṣavijayā dhārañi in developing print technology in China.

2 As for the dhäranī pillar, see Paul F. Copp, The Body Incantatory: Spells and the Ritual Imagination in Medieval Chinese Buddhism (New York: Columbia University Press, 2014), 141-196; Liu Shufen 劉淑芬, “Jingchuang zhi xingzhi, xingzhi he laiyuan: jingchuang yanjiu zhi er” 經幢的形制、性質和來源經幢研究之二, Zhongyang yanjiuyuan lishi yuyan yanjiusuo jikan 中央研究院歷史語言研究所集刊 68, no. 3 (1997); Liu Shufen 劉淑芬, Miezui yu duwang: Foding zunsheng tuoluoni jingchuang zhi yanjiu 滅罪與度亡: 佛頂尊勝陀羅尼經幢之研究 (Shanghai: Shanghai guji chubanshe, 2008).

3 After the Tang dynasty, the Ușnịșavijayā dhāraṇi as well as various dhāraṇi were inscribed on the dhāraṇi pillar. As for the dhāranī pillars from the Liao and Jin dynasties, see Zhang Mingwu 張明悟, Liao Jin jingchuang yanjiu 辽金经幢研究 (Beijing: Zhongguo kexue jishu chubanshe, 2013).

4 Sinp'yŏn chejong kyojang ch'ongnok 新編諸宗教藏總錄, T. 55, no. 2184. 


\section{Text and Image: Early Liao Mandala and Tang Scriptures}

This paper's investigation into the Uș̣niṣavijayā Dhāraṇi Mandala begins from a gold mandala excavated from Chaoyang North Pagoda (1043-44) (Fig. 1). The production of this mandala dated to 1043 was supervised by the Great Master Xuanyan 宣演大師, a high-ranking monk from the Supreme Capital of Liao. ${ }^{5}$ Reflecting his deep knowledge of the Buddhist scriptures, the mandala exhibits close interaction between text and image. As shown below, it bears the standard iconography that was based on textual sources from the Tang. Following the Buddhist scriptures, it adopts the simplest form of iconography without any additional deities or decorations aside from those mentioned in the scriptural instructions.

The mandala was found when archaeologists opened the relic depository in the pagoda's twelfth eave in 1988. ${ }^{6}$ It was discovered in the small jingta 經塔, or "sutra-pagoda," that had been placed at the depository's center (Fig. 2). Among the four layers of cylindrical metal that formed the main body of the "sutra-pagoda," the third layer, made of pure gold, bore an engraving of the mandala (Fig. 1). In the

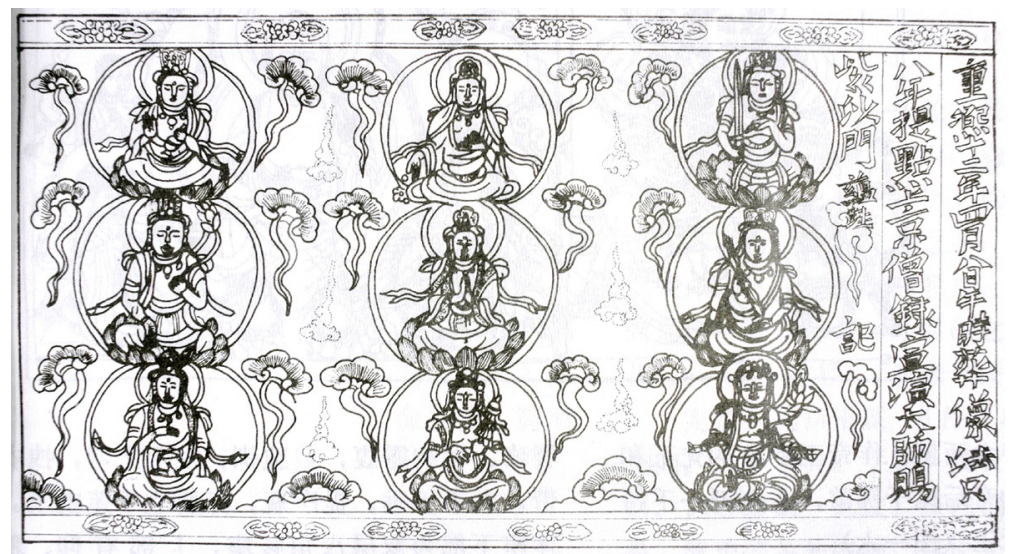

Fig. 1. Drawing of the mandala on the third layer of the sutra-pagoda excavated from Chaoyang North Pagoda. Gold. Liao dynasty 1043 [Source: Liaoning sheng wenwu kaogu yanjiusuo and Chaoyang shi Beita bowuguan, eds., Chaoyang Beita, Fig. 24-1]

5 As for the Great Master Xuanyan (also known as the monk Yungui 藴珪), and his supervision of Chaoyang North Pagoda’s construction, see Youn-mi Kim, "The Hidden Link: Tracing Liao Buddhism in Shingon Ritual," Journal of Song-Yuan Studies 43, Special Issue on the Liao Dynasty (2013 [published in 2015]): 15-161.

6 For the excavation report, see Liaoning-sheng wenwu kaogu yanjiusuo 遼寧省文物考古研究所 and Chaoyang shi Beita bowuguan 朝陽市北塔博物館 eds., Chaoyang Beita: Kaogu fajue yu weixiu gongcheng baogao 朝陽北塔: 考古發掘與維 修工程報告 (Beijing: Wenwu chubanshe, 2007).

7 A stone stele placed before the relic depository records the most important objects enshrined in the depository. The list includes the term jingta, which refers to this metal miniature pagoda that encased a long roll of silver plate engraved with Buddhist dhāranīs. The sutras found within this miniature pagoda were mainly Buddhist incantations. 


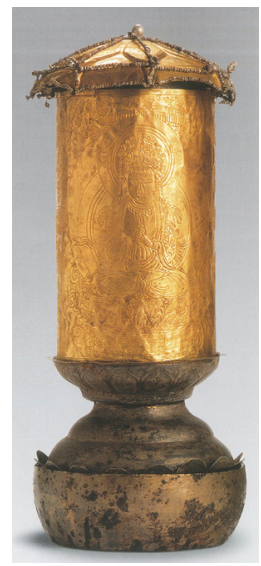

Fig. 2. Sutra-pagoda excavated from Chaoyang North Pagoda. Gold and silver. Liao dynasty 1043 [Source: Liaoning sheng wenwu kaogu yanjiusuo and Chaoyang shi Beita bowuguan, eds., Chaoyang Beita, color plate 41-1] rectangular frame of this mandala, eight bodhisattvas surround a Buddha in the center. The central Buddha's wisdom-fist mudrā (zhiquanyin 智拳印) — holding his left index finger in his right fist-indicates that he is Vairocana Buddha. The right side of the mandala has three lines of inscription, which include the official rank and name of the Great Master Xuanyan who supervised the construction of Chaoyang North Pagoda, suggesting the importance of this mandala in the ritual function of the pagoda as a whole. The relic depository, where the gold mandala was discovered, had one more mandala engraved into the stone of the relic depository's main wall, ${ }^{8}$ which further attests to the significance of the mandalas' role in the relic depository.

The relic depository, as I have discussed elsewhere, was designed as a ritual altar for activating the thaumaturgic power of the Ușnişavijaya dhäraṇi. ${ }^{9}$ Suffice it to say, though, that the gold and stone mandalas were central ritual apparati that transformed the relic depository into a ritual altar for the Uṣnịșavijaya dhāranī. In particular, the "sutra-pagoda," where the gold mandala was discovered, played the role of benzun 本尊, or main object of veneration, in the Uș̣n̄ṣavijaya à dhärañi ritual practiced in Liao.

Now let us examine the visual characteristics of the mandalas from Chaoyang North Pagoda. The Liao mandalas had a simple square format in which only eight bodhisattvas and a central Vairocana Buddha were portrayed. Among the dozens of Buddhist scriptures that mention the Eight Great Bodhisattvas, ${ }^{10}$ the textual sources for the mandala were Ritual Manual for Chanting the Ușnịsavijayā dhärañi and Sutra of the Eight Great Bodhisattvas Mandala, both of which were translated by Amoghavajra. ${ }^{11}$ The former is the only sutra that instructs practitioners to make a mandala of the Eight Great Bodhisattvas with Vairocana Buddha seated in the center. The Liao mandala's square format also originates from the Ritual Manual. For the chanting ritual of the Uṣnissavijaya a dhäran̄i, according to its

8 The main wall of the relic depository, from which the gold mandala was excavated, was engraved with the same type of mandala, but rotated $45^{\circ}$ clockwise. For an image of this mandala on the wall, see Liaoning-sheng wenwu kaogu yanjiusuo and Chaoyang shi Beita bowuguan eds., Chaoyang Beita, fig. 21-2.

9 Kim, "The Hidden Link," 117-170.

10 For a list of these scriptures, see Yang Hijŏng (Yang Heejung) 양희정, “Han'guk p'altae posal tosang yǒn'gu” 韓國 八大菩薩 圖像研究, M.A. thesis (Seoul National University, 2006), 5-9. For a detailed analysis of the Eight Great Bodhisattvas in Liao Buddhism and Buddhist art, see Sŏng Sǒyŏng 成敘永. “Liao dai bada pusa zaoxiang yanjiu” 遼代八大菩薩造像研究, Liao Jin lishi yu kaogu遼金曆史與考古7, no. 1 (2017): 81-109.

11 Kim, “The Hidden Link," 125-130; Foding zunsheng tuoluoni niansong yigui fa 佛頂尊勝陀羅尼念誦儀軌法, T. 19, no. 972; and Bada pusa mantuoluo jing 八大菩薩曼茶羅經, T.20, no. 1167: 675b. 
instructions, the practitioner should prepare a square mandala divided into nine seats to enshrine Vairocana Buddha and each bodhisattva. ${ }^{12}$ A silver plate inscribed with the Ușnịșavijayā dhāraṇi was enshrined inside the "sutra-pagoda," which further testifies to the function of the gold mandala forming the body of the "sutra-pagoda" as an enactment of the dhäranī (Fig. 3).

Fortunately, the gold mandala has been excavated intact, and the attributes in the hands of the eight bodhisattvas are clearly legible. The attributes portrayed in the gold mandala from Liao conform to those of the Eight Great Bodhisattvas described in the Sutra of the Eight Great Bodhisattvas Mandala exactly. ${ }^{13}$ As described in the sutra, for example, Avalokiteśvara bodhisattva, on the proper right side of Vairocana Buddha, holds a lotus flower (Fig. 4). ${ }^{14}$ Not only Avalokiteśvara bodhisattva but all eight bodhisattvas have attributes that conform exactly to those described in the scripture, as shown Table 1.

This gold mandala from the Liao period is very rare in its perfect consonance between image and text. Its meticulous fidelity to the Sutra of the Eight Great Bodhisattvas Mandala makes it a notable case in the history of Buddhist art. Before the Liao dynasty, it is difficult to find a representation of the Eight Great Bodhisattvas whose eight attributes all conform to the sutra. ${ }^{15}$ Such iconographic fidelity to the sutra can be found only in the depictions of the Eight Great Bodhisattvas in later Japanese compendia of Buddhist iconographies produced after the 12th century. ${ }^{16}$ Although the Eight Great Bodhisattvas had

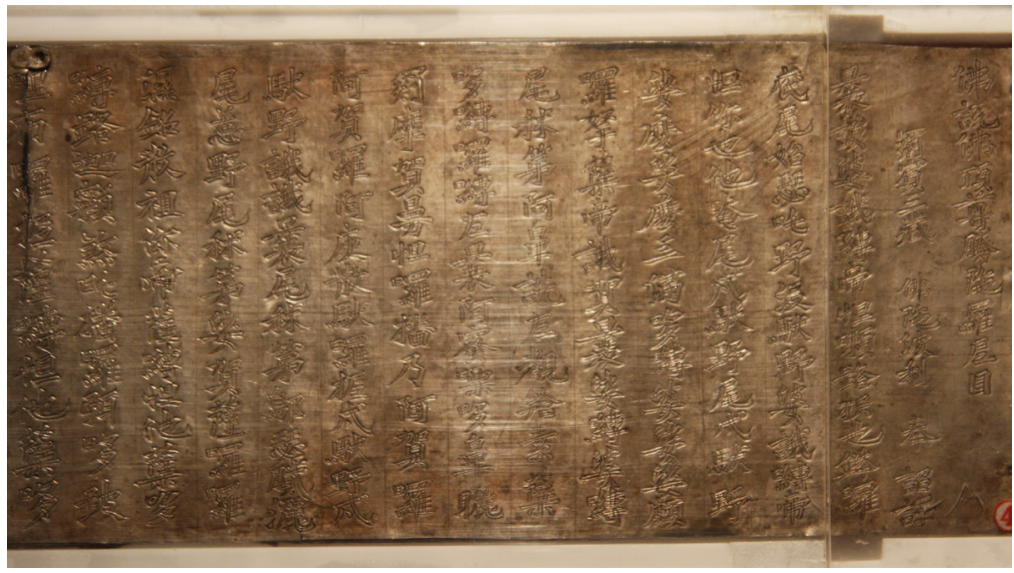

Fig. 3. Ușnịșavijayā dhārañi engrave on a silver plate excavated from Chaoyang North Pagoda. Liao dynasty 1043 [Photograph by Youn-mi Kim]

12 Foding zunsheng tuoluoni niansong yigui fa, T. 19, no. 972: 364b-c. For a further comparison of Chaoyang North Pagoda mandalas and the ritual manual, see Kim, “The Hidden Link," 122-130.

13 Bada pusa mantuoluo jing 八大菩薩曼茶羅經, T.20, no. 1167: 675b.

14 Bada pusa mantuoluo jing, T.20, no. 1167: 675b.

15 Youn-mi Kim, "Eternal Ritual in an Infinite Cosmos: The Chaoyang North Pagoda (1043-1044)," PhD Dissertation (Harvard University, 2010), 123-124.

16 Ibid, 123, footnote 193 . 


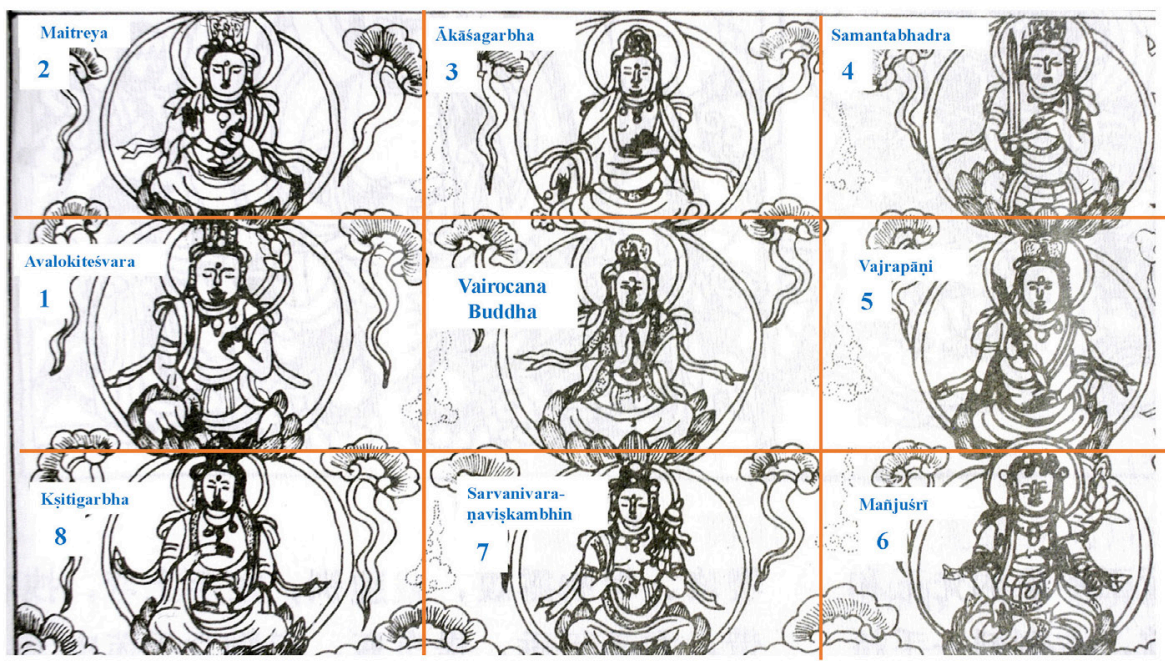

Fig. 4. Eight Great Bodhisattvas and Vairocana Buddha in the gold mandala from Chaoyang North Pagoda [Diagram by Youn-mi Kim]

Table 1. Comparison of Attributes

\begin{tabular}{|l|c|c|}
\hline Bodhisattva names in the sutra & $\begin{array}{c}\text { Sutra of the Eight Great } \\
\text { Bodhisattvas Mandala }\end{array}$ & $\begin{array}{c}\text { Gold Mandala from Chaoyang } \\
\text { North Pagoda }\end{array}$ \\
\hline $\begin{array}{l}\text { 1. Avalokiteśvara } \\
\text { (Guanzizai pusa 觀自在菩薩) }\end{array}$ & lotus flower & lotus flower \\
\hline $\begin{array}{l}\text { 2. Maitreya } \\
\text { (Cishi pusa 慈氏菩薩) }\end{array}$ & bottle \\
\hline $\begin{array}{l}\text { 3. Ākáśagarbha } \\
\text { (Xukongzang pusa 虛空藏菩薩) }\end{array}$ & jewel \\
\hline $\begin{array}{l}\text { 4. Samantabhadra } \\
\text { (Puxian pusa 普賢菩薩) }\end{array}$ & sword & jewel \\
\hline $\begin{array}{l}\text { 5. Vajrapāṇi } \\
\text { (Jingangshou pusa 金剛手菩薩) }\end{array}$ & sword \\
\hline $\begin{array}{l}\text { 6. Mañjuśri } \\
\text { (Manshushili tongzhen pusa } \\
\text { 曼殊室利童眞菩薩) }\end{array}$ & five-branched vajra on a lotus \\
\hline $\begin{array}{l}\text { 7. Sarvanivaranavișkambhin } \\
\text { (Chugaizhang pusa 除蓋障菩薩) }\end{array}$ & flower & vajra \\
\hline $\begin{array}{l}\text { 8. Kșitigarbha } \\
\text { (Dizang pusa 地藏菩薩) }\end{array}$ & five-branched vajra on a lotus \\
\hline
\end{tabular}


been portrayed in various mandalic forms during previous dynasties, including those in the murals in Dunhuang, ${ }^{17}$ almost none shows such perfect conformity with the sutra. ${ }^{18}$ Attributes of at least one or two bodhisattvas deviated from the scriptural description in the mandalas before the Liao dynasty.

Besides the eight attributes, this Liao mandala includes further details that conform to the sutra, suggesting that it was carefully designed in reference to the Sutra of the Eight Great Bodhisattvas Mandala. ${ }^{19}$ Explanations in the sutra include which hand holds the attribute and what mudra the other hand forms. The relevant passage of the sutra reads:

Then, say the mantra of the Buddha: 20 "Oṃ mahāmira sāvāha."

Then, visualize the Buddha in the mandala, whose body is gold-colored. He has thirty-two sacred bodily marks and sits on a lotus pedestal. ${ }^{21}$

Next, say the mantra of Avalokiteśvara bodhisattva: "Hūṃ hrī hakvanama sriye sāvāha."

Then, visualize Avalokiteśvara in the mandala, whose body is red, his right hand holding a lotus flower, and his left hand forming the varada mudrā (the wish-granting gesture). On his crown is Amitäbha Buddha.

Next, say the mantra of Maitreya bodhisattva: "Mehariya sāvāha."

Visualize Maitreya bodhisattva [seated] behind Avalokiteśvara bodhisattva. His body is gold-colored. His left hand holds a bottle, and his right hand forms the abhaya mudrä (the fear-not gesture). On his crown is a small stūpa. He is seated with his legs crossed.

Next, say the mantra of Ākāśagarbha bodhisattva: "Ā avaya sāvāha."

Visualize Ākāśagarbha bodhisattva seated behind the Buddha. His left hand is placed before his heart and holds a jewel, while his right hand in the varada $\mathbf{m u d r a ̈}$ sends out immeasurable treasures.

Next, say the mantra of Samantabhadra bodhisattva: "Hrī avaya sāvāha."

Visualize Samantabhadra bodhisattva seated on the left of Ākāśagarbha bodhisattva. He wears a crown with the images of the Five Buddhas on his gold-colored body, holding a sword in his right hand and forming the varada $\boldsymbol{m u d r a}$ with his left. He sits with his legs crossed.

17 For the Eight Great Bodhisattvas appearing in the mandalas from Dunhuang, see Michelle C. Wang, The Visual Culture of Esoteric Buddhism at Dunhuang (Leiden and Boston: Brill, 2018).

18 Yang Hǔi-jŏng (Yang Heejung) 양희정, "Koryǒ sidae Amit'a p'altae posalto tosang yǒn'gu” 고려시대 아미타팔대보살도 도상 연구, Misul sahak yŏn'gu 美術史學研究 257 (2008): 78.

19 It is probably because the Great Master Xuanyan, who supervised the construction of Chaoyang North Pagoda, also supervised the production of the mandala.

20 There is no clear boundary between mantra and dhäranī, although the former is usually shorter. For more on mantra, see Ryūichi Abe, The Weaving of Mantra: Kükai and the Construction of Esoteric Buddhist Discourse (Columbia University Press, 1999), 5-6, 12-13, 262-264.

21 Every Buddha has the same thirty-two sacred bodily marks (三十二相), which include white tufts of shining hair between the eyebrows (Sk. ùrṇā) and a protuberance on the crown (Sk. uṣnịșa). 
Next, say the mantra of Vajrapāṇi bodhisattva: "Oṃ vamrava sāvāha."

Visualize Vajrapāni bodhisattva seated on the left of the Buddha. His right hand holds a vajra (adamantine scepter), and his left hand rests on his groin. He wears a crown with the image of the Five Buddhas. His body is blue and he sits with his legs crossed.

Next, say the mantra of Mañjuśrī bodhisattva in the shape of a boy: "Śrī sarama sāvāha."

Visualize Mañjuśri bodhisattva seated before Vajrapāni bodhisattva. His appearance is that of a young boy with five topknots. His left hand holds a blue lotus flower on which there balances a five-

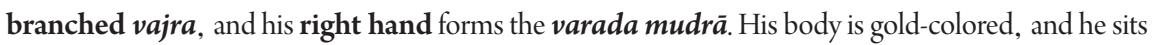
with his legs crossed.

Next, say the mantra of Sarvanivaraṇaviṣkambhin bodhisattva: "Nikvarana sāvāha."

Visualize Sarvanivaraṇaviṣkambhin bodhisattva seated on the right of Mañjuśri bodhisattva. His body is gold-colored. His left hand holds a wish-fulfilling flag, and his right hand forms the varada $\boldsymbol{m u d r a}$. He is seated with his legs crossed.

Next, say the mantra of Kṣitigarbha bodhisattva: "Gasā harā sāvāha."

Visualize Kșitigarbha bodhisattva seated before the Buddha. ${ }^{22}$ His crown is decorated with jewels. His face, whose countenance shows compassion for all sentient beings, is lustrous, gentle and calm. In his left hand, he holds a bowl under his navel. He holds his right palm downward while, with thumb to index finger, he consoles all sentient beings. ${ }^{23}$

The eight bodhisattvas in the gold mandala from Chaoyang North Pagoda faithfully adhere to every detail of this description. The hands of all bodhisattvas - except for Avalokiteśvara, whose left and right hands are transposed - fastidiously follow the account in this sutra (Table 2). For example, the third bodhisattva, Ākāśagarbha, seated above Vairocana Buddha (i.e., behind the Buddha) holds a jewel before his chest with his left hand, conforming to the sutra (Fig. 5). His right hand forms the varada $m u d r a \bar{a}$, in which he shows his palm to signify that he will grant one's wishes. Small beads dropping from this hand visually represent a phrase from the sutra, "his right hand in the varada mudrã sends out immeasurable treasures." As for Mañjuśri bodhisattva in the lower right, not only his hands but also his hairstyle follow the sutra, "His appearance is that of a young boy with five topknots" (Fig. 4). Unlike other bodhisattvas in the mandala who wear tall crowns, Mañjuśrí bodhisattva has topknots, a common

22 This part of the sutra has an obvious mistake, in that the position of this bodhisattva overlaps with that of Sarvanivaranavișkambhin bodhisattva, who is also described as being seated in front of the Buddha. Since the sutra describes the bodhisattvas in a clockwise manner, starting with Avalokiteśvara bodhisattva, Kșitigarbha bodhisattva should be on the right of Sarvanivaranavișkambhin bodhisattva. Many of the surviving Eight Great Bodhisattvas Mandalas place Kṣitigarbha bodhisattva on the right of Sarvanivaranavișkambhin bodhisattva.

23 Bada pusa mantuoluo jing, T. 20, no. 1167: 675b-c. English translation by the author. The names and attributes of the bodhisattvas are marked in bold by the author. 
Table 2. Comparisons of the Eight Great Bodhisattvas' Left and Right Hands

\begin{tabular}{|c|c|c|c|c|}
\hline \multirow[t]{2}{*}{ Bodhisattvas } & \multicolumn{2}{|c|}{$\begin{array}{l}\text { Sutra of the Eight Great } \\
\text { Bodhisattvas Mandala }\end{array}$} & \multicolumn{2}{|c|}{$\begin{array}{l}\text { Gold Mandala from Chaoyang North } \\
\text { Pagoda }\end{array}$} \\
\hline & Left Hand & Right Hand & Left Hand & Right Hand \\
\hline 1. Avalokiteśvara & varada mudrā & lotus flower & lotus flower & varada mudrā \\
\hline 2. Maitreya & bottle & abhaya mudrā & bottle & abhaya mudrā \\
\hline 3. Ākāśagarbha & $\begin{array}{l}\text { jewel placed in } \\
\text { front of heart }\end{array}$ & $\begin{array}{l}\text { varada mudrā } \\
\text { sending out } \\
\text { countless treasures }\end{array}$ & $\begin{array}{l}\text { jewel placed in } \\
\text { front of heart }\end{array}$ & $\begin{array}{l}\text { varada mudrā } \\
\text { sending out } \\
\text { countless treasures }\end{array}$ \\
\hline 4. Samantabhadra & varada mudrā & sword & varada mudrā & sword \\
\hline 5. Vajrapāṇi & $\begin{array}{l}\text { hand placed on } \\
\text { groin }\end{array}$ & vajra & $\begin{array}{l}\text { hand placed on } \\
\text { groin }\end{array}$ & vajra \\
\hline $\begin{array}{l}\text { 6. Mañjuśrī } \\
\text { * appearance of a young boy } \\
\text { with five topknots }\end{array}$ & $\begin{array}{l}\text { five-branched } \\
\text { vajra on a lotus } \\
\text { flower }\end{array}$ & varada mudrā & $\begin{array}{l}\text { five-branched } \\
\text { vajra on a lotus } \\
\text { flower }\end{array}$ & varada mudrā \\
\hline 7. Sarvanivaraṇaviṣkambhin & wish-fulfilling flag & varada mudrā & wish-fulfilling flag & varada mudrā \\
\hline 8. Kșitigarbha & $\begin{array}{l}\text { bowl placed under } \\
\text { navel }\end{array}$ & $\begin{array}{l}\text { right palm facing } \\
\text { down }\end{array}$ & $\begin{array}{l}\text { bowl placed under } \\
\text { navel }\end{array}$ & $\begin{array}{l}\text { right palm facing } \\
\text { down }\end{array}$ \\
\hline
\end{tabular}

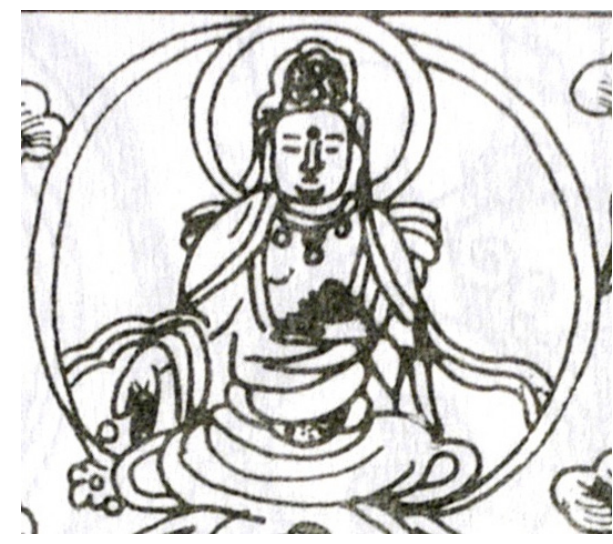

Fig. 5. Ākāśagarbha Bodhisattva, detail of Fig.1. hairstyle for young boys in premodern China.

As for the placement of each bodhisattva in the Liao gold mandala, it follows the instructions from the Ritual Manual, ${ }^{24}$ clarifying its relationship with the scriptures from the Tang dynasty. The Ritual Manual instructs that the practitioner should place the first bodhisattva Avalokiteśvara to the right of Vairocana Buddha and place the following bodhisattvas in the clockwise direction when making the mandala for the chanting ritual of the Uṣnịsavijaya dhāraṇi. ${ }^{25}$ The placement in the Liao mandala conforms to this instruction precisely (Fig. 4). Also following this ritual manual, the Liao mandala places Vairocana Buddha in the center.

This placement of Vairocana is the distinctive feature of the Eight Great Bodhisattvas Mandala of

24 For a comparison of Chaoyang North Pagoda mandalas and the ritual manual, see Kim, "The Hidden Link," 128-130.

25 Foding zunsheng tuoluoni niansong yiguifa, T.972, 19:364b-c. 
Liao. As far as I know, no mandala with the Eight Great Bodhisattvas from Liao places a different kind of Buddha at the center. Unlike Liao, other dynasties, including Tang and Koryǒ (918-1392), had the Eight Great Bodhisattvas Mandalas with Rocana Buddha or Amitābha Buddha at the center. ${ }^{26}$ Earlier examples in India had Šakyamuni Buddha at the center. In the Liao, however, the Eight Great Bodhisattvas Mandala always featured Vairocana Buddha in the center. Only those with Vairocana Buddha in the center functioned as mandalas for the Uṣnisṣavijaya a dhāraṇi ritual. ${ }^{27}$ In other words, the Eight Great Bodhisattvas Mandala in the Liao context was none other than the Ușnịsavijayā Dhärañi Mandala, which reflects the height of Uș̣ịsavijayā dhāraṇi practice in the Liao dynasty.

\section{Three-dimensional Mandala}

Unlike the mandala from Chaoyang North Pagoda that was discovered in intact, the original iconography of the mandala in Yingxian Timber Pagoda (ca. 1056) is more challenging to piece together due to its damaged condition. On the uppermost floor of Yingxian Timber Pagoda, a five-story wooden pagoda in present-day Ying County, Shanxi Province (Fig. 6), the mandala was situated. Each of its stories featured a different group of Buddhist statues. The nine statues relevant to our discussion-a Buddha and eight bodhisattvas — are enshrined in the pagoda's fifth story (Fig. 7).

The wisdom-fist mudrā of the Buddha statue indicates that he is Vairocana Buddha. But the hands of all eight bodhisattvas, sadly, have been lost. In this state, it is impossible to tell what kinds of attributes they held. After Lü Jianfu's book on the history of Chinese esoteric Buddhism briefly mentioned that the fifth story of this pagoda had been installed with an altar of the Eight Great Bodhisattvas Mandala, ${ }^{28}$ quite a few papers called these statues the Eight Great Bodhisattvas. ${ }^{29}$ Recently, Li Jingjie suggested that

26 Kim, "Eternal Ritual in an Infinite Cosmos," 124-127. For more on the Eight Great Bodhisattvas and Mandalas of the Eight Great Bodhisattvas produced in India, see Pratapaditya Pal, "A Note on the Mandala of the Eight Bodhisattvas", Archives of Asian Art 26. (1972-1973): 71-73; Nancy Hock, "Buddhist Ideology and the Sculpture of Ratnagiri, Seventh through Thirteenth Centuries," PhD Dissertation (University of California-Berkeley, 2005); Radha Banerjee, Ashtamahabodhisattva: The Eight Great Bodhisattvas in Art and Literature (New Delhi: Abha Prakashan, 1994); Bimal Bandyopadhyay, Buddhist Centres of Orissa: Lalitagiri, Ratnagiri, and Udayagiri (New Delhi: Sundeep Prakashan, 2004); Matsunaga Keiji 松長恵史, Indoneshia no Mikkyō インドネシアの密教 (Kyōto: Hōzōkan, 1999), 64-103; Geri Hockfield Malandra, Unfolding a Mandala: The Buddhist Cave Temples at Ellora (New York: State University of New York Press, 1993). For more on the Eight Great Bodhisattvas in Korea, see Mun Myǒngdae 문명대, "Noyǒng ŭi Amit’a Chijang purhwa e taehan kochal” 노영의 아미타 지장불화에 대한 고찰, Misul charyo 미술자료 25 (1979); 47-57; Chŏng, Ut’aek (Chung Woo-thak) 정우택, Kōrai jidai Amida gazō no kenkyū 高麗時代阿弥陀画像の研究 (Kyōto: Nagata bunshōdō, 1990), 133-183; Yang, "Han'guk p'altae posal tosang yǒn'gu"; Yang, "Koryǒ sidae Amit'a p'altae posalto tosang yǒn'gu”; and Ku Chin-gyǒng 구진경, "Koryǒ Chosŏn sidae Amit'a p'altae posalto ǔi pigyo yŏn'gu” 고려 조선시대 아미타 팔대보살도 비교 연구, M.A. thesis (Dongguk University, 2004).

27 Kim, "The Hidden Link,"117-170.

28 Lü Jianfu 呂建福, Zhongguo mijiao shi 中國密教史 (Beijing: Zhongguo shehui kexue chubanshe, 2011), 470-417.

29 For example, see Yu Bo 于博, “You bada lingta tuxiang guankui Liao dai fojiao xinyang” 由八大靈塔圖像管窺遼代佛教信仰 


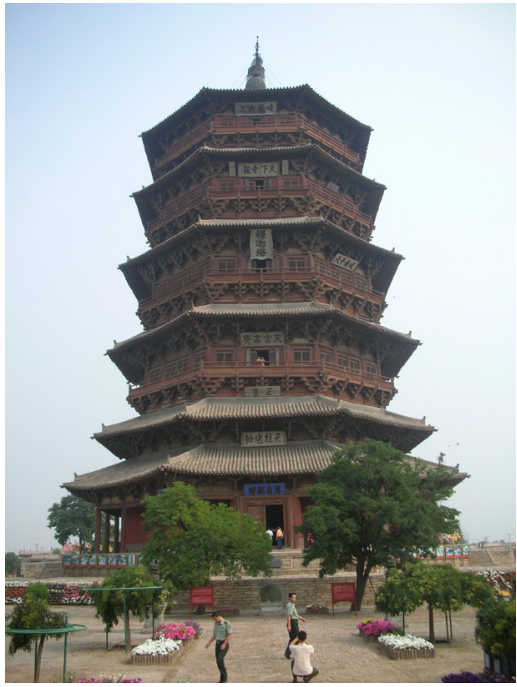

Fig. 6. Yingxian Timber Pagoda. Liao dynasty, ca. 1056. Ying County, Shanxi Province, China [Photograph by Youn-mi Kim, 2007]

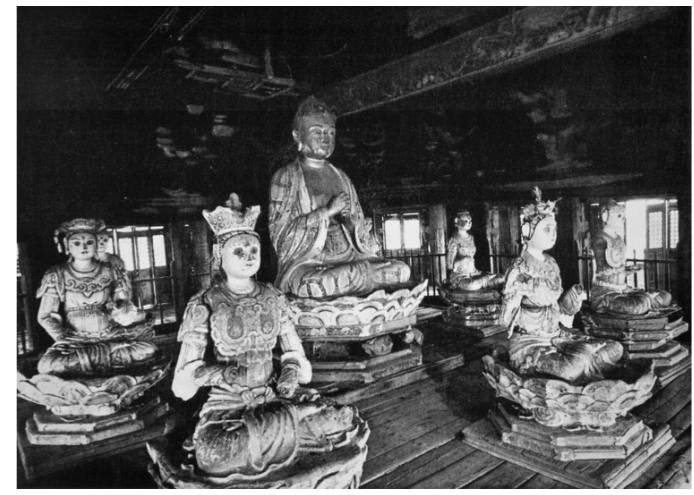

Fig. 7. The fifth floor of Yingxian Timber Pagoda. Liao dynasty, ca. 1056. Ying County, Shanxi Province, China [Source: Chen Mingda, Yingxian muta, plate 130]

these may be the four perfection bodhisattvas and the four offerings bodhisattvas from the Perfected-Body Assembly (Chengshen hui 成身會) in the Diamond World Mandala. ${ }^{30}$ These previous studies, however, did not attempt to identify individual statues at Yingxian Timber Pagoda. Because the hands were destroyed, unfortunately it has been assumed that the statues cannot be respectively identified. They were simply assumed to be the Eight Great Bodhisattvas or the eight bodhisattvas from the Diamond World Mandala, without concrete evidence from careful visual analyses of the statues.

Comparisons with the Tang scriptures and relevant Liao mandalas, however, make it possible to reconstruct the lost iconography of each bodhisattva statue at Yingxian Timber Pagoda. Crucial for this comparison are the black-and-white photographs that were taken in 1962 and published in the monograph Yingxian muta by Chen Mingda 陳明達 (1914-1997), ${ }^{31}$ the first scholar to examine Yingxian Timber Pagoda using the modern discipline of architectural history from the west. These photographs were taken before restoration of the statues began. The modern restoration gave new hands

Dongbei shidi 東北史地 no. 5 (2015): 30; Luo Zhao 羅炤, “Yingxian muta suxiang de zongjiao chongbai tixi” 應縣木塔塑像 的宗教崇拜體系, Yishu-shi yanjiu 藝術史研究 12 (2010): 198-203; Sǒng, “Liao dai bada pusa zaoxiang yanjiu,” 84; and Wei-Cheng Lin, "Performing Center in a Vertical Rise: Multilevel Pagodas in China's Middle Period," Ars Orientalis 46 (2016): 115 .

30 Li Jingjie 李靜傑, “Shanbei Song Jin shiku Dari rulai tuxiang leixing fenxi” 陝北宋金石窟大日如來圖像類型分析, Gugong bowuyuan yuankan 故宮博物院院刊 167, no. 3 (2013): 127. Li does not specify whether the “four offerings bodhisattvas" are the four inner offerings bodhisattvas (nei gongyang pusa 內供養菩薩) or the four outer offerings bodhisattvas (wai gongyang pusa 外供養菩薩) from the Diamond World Mandala.

31 Chen Mingda 陳明達, Yingxian muta 應縣木塔 (Beijing: Wenwu chubanshe, 1966). 
to the broken bodhisattvas, but none of them holds an attribute (Fig. 8). However, as this paper will suggest, each of the eight originally held an attribute suited to their iconography.

The black-and-white photographs from 1962 thankfully allow us to examine the status of the eight bodhisattvas before this last restoration. Although the hands and their attributes were lost, the remaining arm parts of the bodhisattvas captured in the photographs offer useful information for identifying them. In the photographs, most of the statues' upper arms and forearms remain in the original state, though the hands have been severed. Except for the completely missing right arm of Mañjuśrī, 15 arms of the bodhisattvas can be discerned in the photographs. In other words, for each bodhisattva, we can deduce which arm was raised and which was lowered, using the photographs.

When identifying a Buddhist deity in art history, we usually refer to iconographic signs such as specific mudrās or attributes. The wisdom-fist mudrā of a Buddha image, for example, is a sign that the Buddha is Vairocana. However, as this paper shows below, the positions of arms can sometimes serve as crucial information for identifying the deities.

Let us first compare and analyze the bodhisattvas in Yingxian Timber Pagoda and Chaoyang North Pagoda's mandala step by step, focusing on their arm positions. According to Ritual Manual for Chanting the Ușnīșavijayā Dhārañi, the bodhisattva to the right of Vairocana Buddha should be Avalokiteśvara, the first bodhisattva among the eight. The following seven in the mandala should be arranged clockwise around the Buddha (Fig. 4). ${ }^{32}$ If so, the statue situated in the west would be the first bodhisattva Avalokiteśvara, while the northwest would be Maitreya, and the last statue in the southwest would be Kșitigarbha. Did the

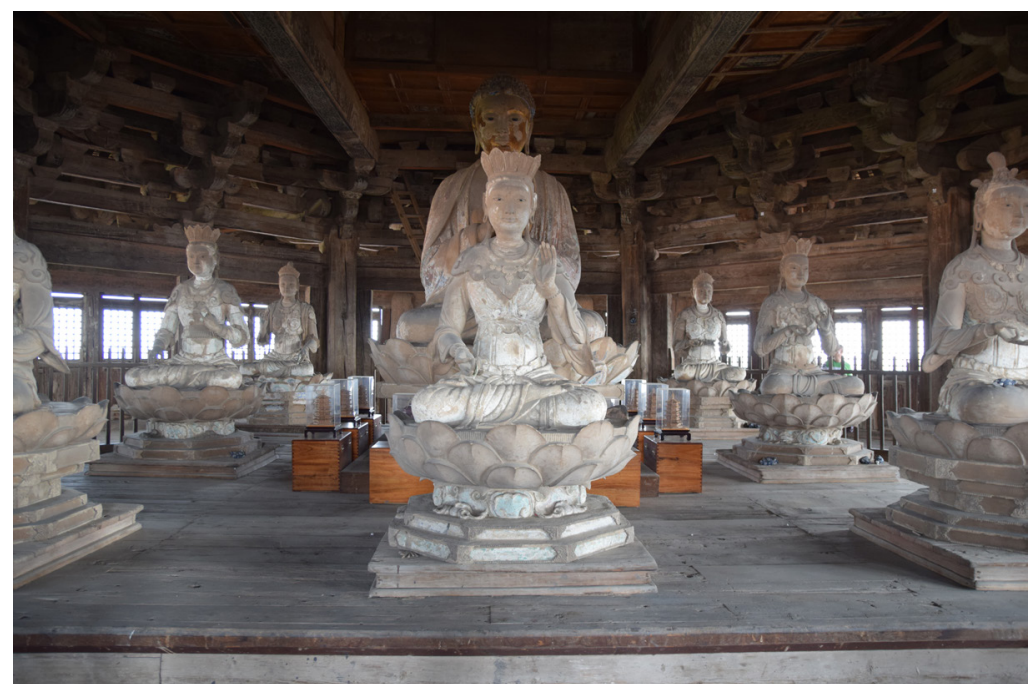

Fig. 8. The fifth floor of Yingxian Timber Pagoda after restoration. Liao dynasty, ca. 1056. Ying County, Shanxi Province, China [Photograph by Youn-mi Kim, 2016]

32 Foding zunsheng tuoluoni niansong yigui fa, T. 19, no. 972: 364b27-c8. 
statues at Yingxian Timber Pagoda actually follow this arrangement? A careful examination of the arm positions of the eight bodhisattvas, as shown below, can offer an answer to this question.

Comparison between the arm positions of the bodhisattvas in Yingxian Timber Pagoda and Chaoyang North Pagoda's mandala shows a high degree of conformity. In the latter, for example, the left forearm of the third bodhisattva Ākāsagarbha, seated behind Vairocana Buddha (i.e., above the Buddha on the two-dimensional mandala), raises to display a jewel before his heart. His right forearm lowers to display the wish-fulfilling gesture (Fig. 5). Its corresponding bodhisattva in Yingxian Timber Pagoda is seated behind Vairocana Buddha (i.e., to the north of the Buddha). In the photograph from 1962, the remaining arm parts inform us that this corresponding bodhisattva originally had a raised left arm and a lowered right arm, just like the two arms of Ākāśagarbha bodhisattva in Chaoyang North Pagoda's mandala (Figs. 5 and 9).

In sum, 10 of the 14 surviving arms of Yingxian

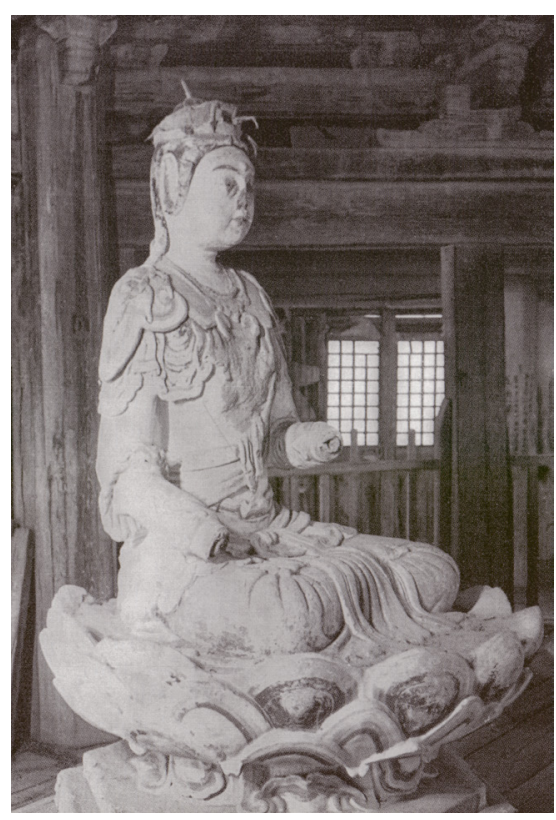

Fig. 9. The bodhisattva statue in the north, fifth floor of Yingxian Timber Pagoda [Source: Chen Mingda, Yingxian muta, plate 134] Timber Pagoda's bodhisattvas conform to those in Chaoyang North Pagoda's mandala in terms of position (Table 3$).{ }^{33} 10$ in 14 may not seem significant, but mathematical calculation shows that such conformity is beyond coincidence. But let us suppose, for a moment, that the eight bodhisattvas at Yingxian Timber Pagoda have no relation with the Uṣnișavijaya Dhäranī Mandala, and that they are merely generic bodhisattvas. In other words, let us suppose that they were created simply to fill the octagonal space of the pagoda's floor with their arms randomly positioned. With 14 arms randomly placed upward or downward, artisans could have made 16,384 different combinations $\left(2^{\wedge} 14=16384\right)$. What is the probability of getting 10 conforming arm positions out of 14 if the Yingxian Timber Pagoda's bodhisattvas were randomly positioned? The calculation of probability shows that if an artisan were to make eight bodhisattvas randomly without knowing the iconography of the Uș̣ịsavijayā Dhāraṇi Mandala, the possibility of ten arms matching would only be 6.1 percent. $^{34}$ This is too small to happen by simple coincidence.

Moreover, among the four cases of deviation from the Chaoyang North Pagoda's mandala (marked

33 In photographs, only the right arm of Mañjuśrī in the southwest and the left arm of Vajrapāni in the west appear to have been destroyed; their original positions are unrecognizable.

$3414 \mathrm{C} 10 \times(1 / 2)^{\wedge} 10 \times(1 / 2)^{\wedge} 4=0.0610961914$. I am thankful to Joon Soo Ryu, the COO of Bitsensing, for kindly calculating this probability. 
Table 3. Arm Positions of the Bodhisattvas at Yingxian Timber Pagoda and Chaoyang North Pagoda

\begin{tabular}{|l|c|c|c|c|}
\hline \multirow{2}{*}{\multicolumn{1}{|c|}{ Bodhisattvas }} & \multicolumn{2}{c|}{$\begin{array}{c}\text { Yingxian Timber Pagoda } \\
\text { (ca. 1056) }\end{array}$} & \multicolumn{2}{c|}{$\begin{array}{c}\text { Chaoyang North Pagoda's } \\
\text { gold mandala (1043) }\end{array}$} \\
\cline { 2 - 5 } & Left Arm & Right Arm & Left Arm & Right Arm \\
\hline \hline 1. Avalokiteśvara & Lowered & Raised & Raised & Lowered \\
\hline 2. Maitreya & Lowered & Raised & Raised & Raised \\
\hline 3. Ākāśagarbha & Raised & Lowered & Raised & Lowered \\
\hline 4. Samantabhadra & Lowered & Lowered & Raised & Lowered \\
\hline 5. Vajrapāṇi & Destroyed & Raised & Lowered & Raised \\
\hline 6. Mañjuśrī & Raised & Destroyed & Raised & Lowered \\
\hline 7. Sarvanivaraṇavișkambhin & Raised & Raised & Raised & Raised \\
\hline 8. Kṣitigarbha & Lowered & Raised & Lowered & Raised \\
\hline
\end{tabular}

in red in Table 3), two seem to be intentional corrections of an error in the previous model: the left and right arms of Avalokiteśvara. As explained above, Avalokiteśvara was the only bodhisattva in Chaoyang North Pagoda's mandala whose left and right arm positions differed from the description in Sutra of the Eight Great Bodhisattvas Mandala. While the sutra describes Avalokiteśvara as having in "his right hand ... a lotus flower, and his left hand forming the varada mudrä," Chaoyang North Pagoda's mandala mistakenly transposed the role of left and right hands (Table 2). By re-transposing the left and right arms, the maker of the Avalokiteśvara statue at Yingxian Timber Pagoda corrected this mistake.

If the transposition of Avalokiteśvara's arms was an intentional correction of the previous model, only two arms (the left arms of Maitreya and Samantabhadra) out of remaining 12 deviate from Chaoyang North Pagoda's mandala without clear reason. Excluding Avalokiteśvara's two arms, 10 arms of Yingxian Timber Pagoda's eight bodhisattvas conform to the model from Chaoyang North Pagoda. To calculate the probability of 10 conforming arm positions out of 12 arms:

$$
12 \mathrm{C} 10 \times(1 / 2)^{\wedge} 10 \times(1 / 2)^{\wedge} 2=0.01611328125
$$

If the arm positions were random, there would be a 0.016 percent chance of such conformity, as the calculation shows. Whether 6.1 or 0.016 percent, the chance that Yingxian Timber Pagoda's eight bodhisattvas were created without referring to Chaoyang North Pagoda's mandala is extremely low. The calculations strongly suggest that Yingxian Timber Pagoda's eight bodhisattvas also represented the Eight Great Bodhisattvas, just as Chaoyang North Pagoda’s mandala did.

Another Liao mandala that can serve as comparison is found on the ground story of Daming 
Pagoda 大明塔 (1098 or earlier) in Ningcheng County, Chifeng, Inner Mongolia (Fig.10). ${ }^{35}$ Each of the four walls in the cardinal directions of this octagonal pagoda has two bodhisattvas carved in relief (Fig.11). ${ }^{36}$ The main wall (i.e., south) bears a relief statue of Vairocana Buddha. Together, these reliefs form a three-dimensional Uṣnịisavijaya Dhärañi Mandala surrounding the body of the pagoda. The attributes of the eight bodhisattvas adorning Daming Pagoda conform to those of Chaoyang North Pagoda, and the hands holding the attributes are the same (Table 4). This suggests that the bodhisattvas from the two pagodas are of the same kind and followed the instructions from Sutra of the Eight Great Bodhisattvas Mandala.

Now that it is clear that the reliefs at Daming Pagoda represent the same group of Eight Great Bodhisattvas that this paper has examined, let us compare their arm positions with those of Yingxian Timber Pagoda's bodhisattvas (Table 5). The result is same as in the comparison with those of

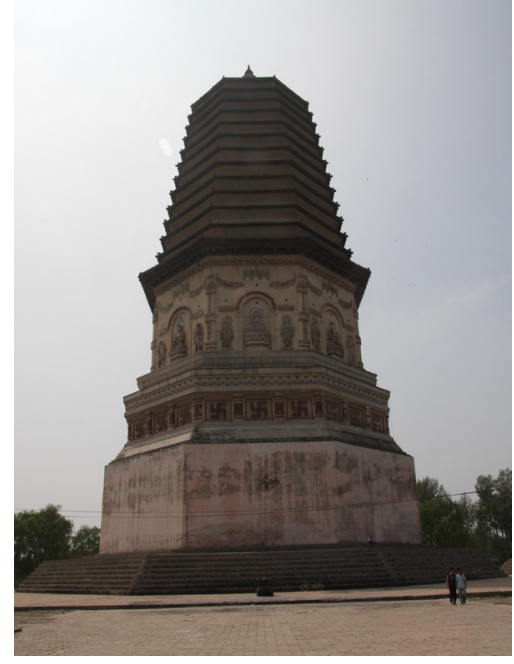

Fig. 10. Daming Pagoda, Ningcheng County, Chifeng, Inner Mongolia. Liao dynasty, latter half of the $11^{\text {th }}$ century [Photograph by Youn-mi Kim, 2009]

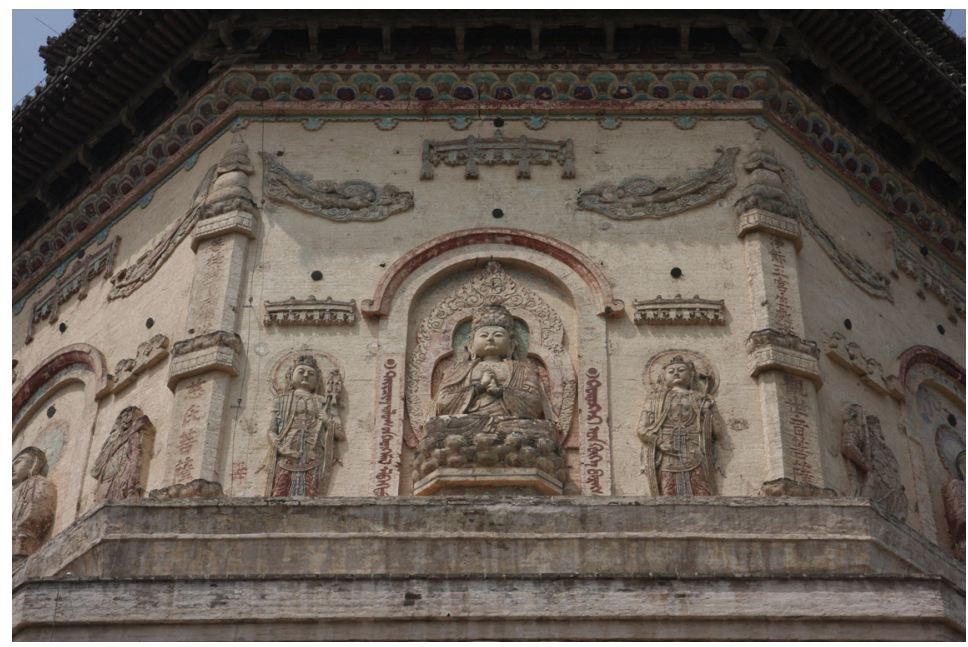

Fig. 11. South wall of Daming Pagoda, Ningcheng County, Chifeng, Inner Mongolia. Liao dynasty, latter half of the 11th century [Photograph by Youn-mi Kim, 2009]

35 As for the construction date of Daming Pagoda, I follow the opinion of Fujiwara Takato 藤原崇, who suggested that the old inscription, “Shouchang sinian” 壽昌四年, discovered inside the pagoda in 1983, is the pagoda’s construction year. Fujiwara Takato, Kŏran pulgyosa yŏn'gu 거란 불교사 연구 (Seoul: Ssiaial, 2020), 266, 288-293.

36 For more about this mandala, see Fujiwara Takato, Kŏran pulgyosa yŏn'gu, 269-288; and Sŏng, "Liao dai bada pusa zaoxiang yanjiu”, 85. Fujiwara and Sóng analyze the mandala as one type of Eight Great Bodhisattvas Mandala. 
Table 4. Arms Position of the Bodhisattvas at Yingxian Timber Pagoda and Chaoyang North Pagoda $^{37}$

\begin{tabular}{|l|c|c|c|c|}
\hline \multirow{2}{*}{ Bodhisattvas } & \multicolumn{2}{|c|}{$\begin{array}{c}\text { Daming Pagoda } \\
\text { (1098) }\end{array}$} & \multicolumn{2}{c|}{$\begin{array}{c}\text { Gold Mandala from Chaoyang } \\
\text { North Pagoda (1043) }\end{array}$} \\
\cline { 2 - 5 } & Attribute & $\begin{array}{c}\text { Hand Holding the } \\
\text { Attribute }\end{array}$ & Attribute & $\begin{array}{c}\text { Hand Holding the } \\
\text { Attribute }\end{array}$ \\
\hline \hline 1. Avalokiteśvara & lotus flower & left & lotus flower & left \\
\hline 2. Maitreya & bottle & left & bottle & left \\
\hline 3. Ākāśagarbha & jewel & left & jewel & left \\
\hline 4. Samantabhadra & sword & right & sword & right \\
\hline 5. Vajrapāṇi & vajra & right & lotus flower & left \\
\hline 6. Mañjuśrí & lotus flower & left & wish-fulfilling flag & left \\
\hline 7. Sarvanivaraṇaviṣkambhin & wish-fulfilling flag & left & bowl & \\
\hline 8. Kṣitigarbha & bowl & left & & \\
\hline
\end{tabular}

Table 5. Arm Positions of the Bodhisattvas at Yingxian Timber Pagoda and Daming Pagoda

\begin{tabular}{|c|c|c|c|c|}
\hline \multirow[t]{2}{*}{ Bodhisattvas } & \multicolumn{2}{|c|}{$\begin{array}{c}\text { Yingxian Timber Pagoda } \\
\text { (ca. 1056) }\end{array}$} & \multicolumn{2}{|c|}{$\begin{array}{l}\text { Daming Pagoda } \\
\text { (1098) }\end{array}$} \\
\hline & Left Arm & Right Arm & Left Arm & Right Arm \\
\hline 1. Avalokiteśvara & Lowered & Raised & Raised & Lowered \\
\hline 2. Maitreya & Lowered & Raised & Raised & Raised \\
\hline 3. Ākāśagarbha & Raised & Lowered & Raised & Lowered \\
\hline 4. Samantabhadra & Lowered & Lowered & Lowered & Lowered \\
\hline 5. Vajrapāṇi & Destroyed & Raised & Lowered & Raised \\
\hline 6. Mañjuśrī & Raised & Destroyed & Raised & Lowered \\
\hline 7. Sarvanivaraṇaviṣkambhin & Raised & Raised & Raised & Lowered \\
\hline 8. Kșitigarbha & Lowered & Raised & Lowered & Raised \\
\hline
\end{tabular}

Chaoyang North Pagoda. Excluding Avalokiteśvara’s arms, 10 arms of Yingxian's bodhisattvas conform to the later Liao mandala from Daming, meaning only a 6.1 percent chance of such conformity being merely coincidence.

Taken together, all of these comparisons suggest that the eight bodhisattva statues of the Liao

37 My photograph of Daming Pagoda's north wall lacks the resolution needed to confirm the attributes. So I referred to the chart in Sŏng, "Liao dai bada pusa zaoxiang yanjiu," p. 94 in order to complete Table 4. 
pagodas at Chaoyang, Yingxian, and Ningcheng embody the same kind of Eight Great Bodhisattvas, and shared an identical visual tradition. In other words, the fifth story of Yingxian Timber Pagoda forms a three-dimensional Uṣnịșavijayā Dhāraṇi Mandala. This offers an answer to our question about whether the arrangement of Yingxian Timber Pagoda's bodhisattvas followed the Ritual Manual for Chanting the Ușniṣavijayā. The comparisons above confirms that they did, and therefore we can identify each of the eight bodhisattvas by name (Fig.12). This means that the bodhisattvas originally held the attributes following the iconography of the Eight Great Bodhisattvas, such as the lotus flower of Avalokiteśvara and the bottle of Maitreya, which unfortunately the modern restorers of the 1970s did not know.

Now that the textual source of Yingxian Timber Pagoda's nine statues has been confirmed as the Ritual Manual for Chanting the Ușnīṣavijayā, we can infer that the fifth story was prepared as a space for the Uṣnīṣavijayā dhārañi ritual. ${ }^{38}$ The manual instructs that one should make a mandala of Vairocana and Eight Great Boddhisattvas in order to activate the power of Ușnịșavijayā dhāraṇi . ${ }^{39}$ As a matter of fact, the entire five stories of Yingxian Timber Pagoda were coherently designed to activate the efficacy of the Ușnịșavijaya dhāraṇi and to embody the contents of the incantation. Due to limitations of space, the

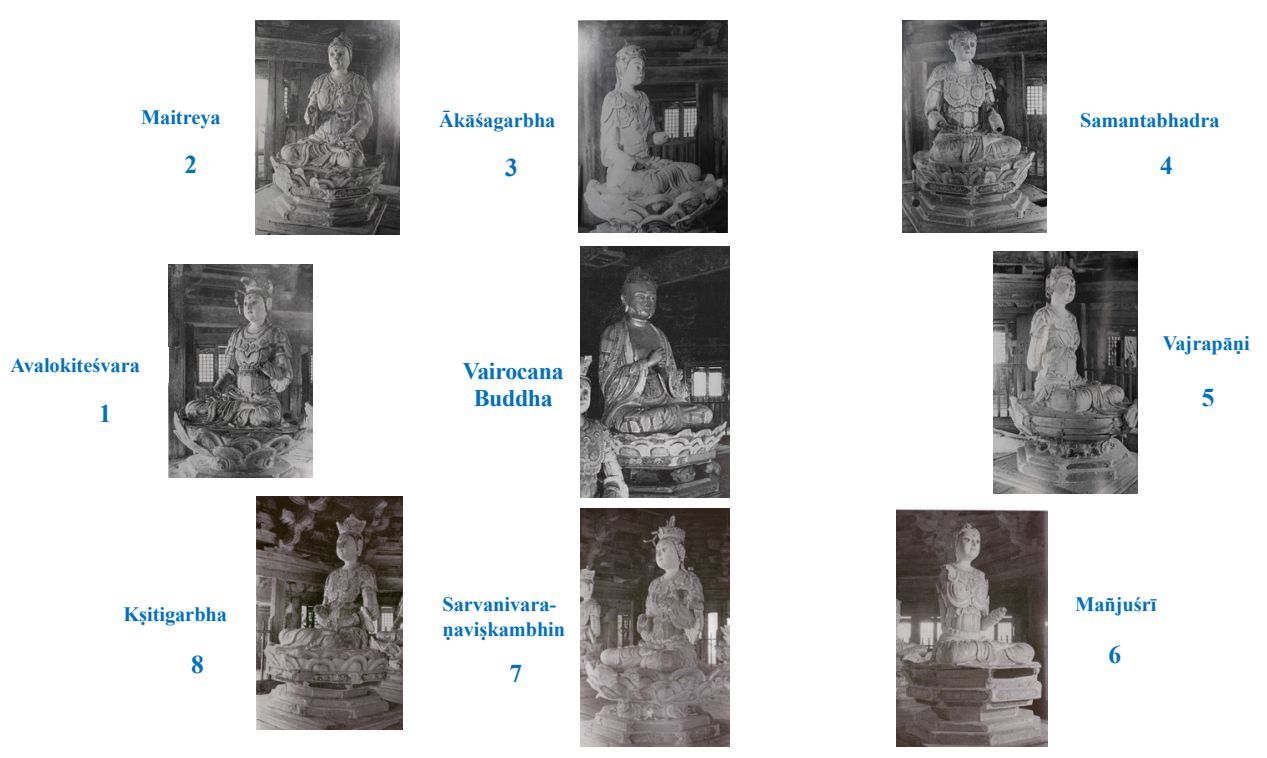

Fig. 12. The eight bodhisattva statues with inferred names according to their location on the fifth floor of Yingxian Timber Pagoda. [Diagram made by Youn-mi Kim using the photographs in Chen Mingda, Yingxian muta, plates132-129]

38 Luo Zao also suggested that the fifth story of the pagoda forms a Uṣniṣavijayā Mandala, but he did not think this dhāraṇi impacted the design of the pagoda's other floors. See Luo, "Yingxian muta suxiang de zongjiao chongbi tixi," 198-201.

39 Foding zunsheng tuoluoni niansong yiguifa, T. 19, no. 972. 
pagoda's relationship with the dhāranī ritual will be discussed in a separate paper; suffice it to say, however, that its five floors were coherently designed to enact and embody the power of the Ușnișavijaya dhäranī as venerators climbed to the uppermost floor, where the ritual process culminates and is completed at the three-dimensional Uṣnịșavijayā Dhāraṇi Mandala. ${ }^{40}$

Returning to the comparisons of the arm positions in Tables 3 and 5, we can further infer that a shared visual model circulated in Liao, and that the Liao makers of the mandalas followed the shared Liao visual model rather than only referring to the ritual manual and the sutra from the Tang dynasty. Unlike the attributes and mudrā which were prescribed in the Sutra of the Eight Great Bodhisattvas Mandala (Tables 1 and 2), many of the arm positions were not bound to the instructions in the sutra. As for Maitreya bodhisattva, for example, the sutra explains, "his left hand holding a bottle, and his right forming the abhaya mudrä." ${ }^{\text {"1 }}$ This description predetermines the position of the bodhisattva's right arm, but not the left: in order to form the abhay a mudrā, the bodhisattva's right arm should be raised to show the palm to venerators. The left arm holding the bottle, however, can be sculpted in a raised or lowered position at the discretion of the artisan. More than half of the arm positions were not prescribed by the sutra's descriptions. The fact that the Liao mandalas at the three pagodas, located in different regions and built in different eras, shared mostly identical arm positions suggests that they shared the same visual model that circulated in eleventh-century Liao. In other words, while following the Tang scripture, the Liao mandalas also shared a visual model that had details not originating from the Tang texts.

\section{Textual Mandala: Modification and Expansion}

In the late eleventh century, the Uṣniṣavijayā Dhāraṇi Mandala in Liao evolved into a much more complicated form with multifarious meanings and functions. A good example of this transformation is a mandala discovered in Baitayu Pagoda 白塔峪塔(1092) in Xingcheng 興城, Liaoning Province (Fig. 13). This mandala is important for several reasons. First, it helps us understand the Liao's modification of the mandala: inclusion of elements of Huayan and Pure Land Buddhism. Second, it offers us a rare opportunity to deduce, though only partly, the contents of the lost writing of the eminent Liao monk Sixiao. As mentioned in the introduction, his writings have not survived, but the mandala in the Baitayu Pagoda built for Sixiao may reflect his exposition and thinking. Lastly, its unique form as a textual mandala - that is, a mandala comprised of texts — gives it a unique place in the history of mandalas in East Asia, demonstrating the innovativeness of Liao Buddhism. ${ }^{42}$

40 For more on the Uș̣ịșavijayā dhāraṇi ritual embodied by Yingxian Timber Pagoda, see my forthcoming article in International Journal of Buddhist Thought and Culture in December 2020.

41 See the translation of Sutra of the Eight Great Bodhisattvas cited above in this paper.

42 Chen Shushi and Tong Qiang, who had a chance to enter the relic depository of Baitayu Pagoda in 2012, published an in-depth analysis of the inscriptions engraved on the depository's ceiling and walls. They also examined the patrons of the pagoda. But they 


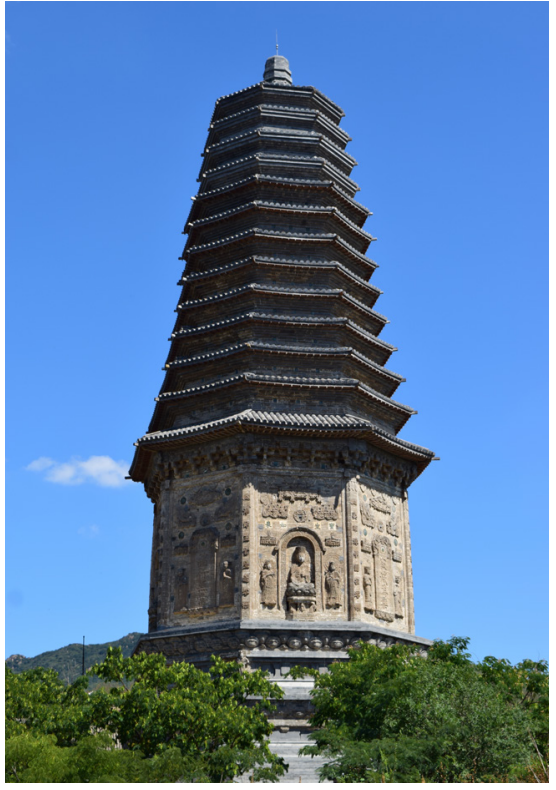

Fig. 13. Baitayu Pagoda, Xingcheng, Liaoning Province. Liao dynasty, 1092 [Photograph by Youn-mi Kim, 2014]
The mandala relevant to our discussion was discovered in Baitayu Pagoda's digong 地宮, the underground relic depository installed inside the platform. This depository was opened once in the early 1980s and then again in 2012 during the pagoda's restoration. Local scholars who entered the relic depository found that the eight walls and ceiling had all been densely engraved with Buddhist scriptures and names of various Buddhist deities. ${ }^{43}$ The mandala was engraved into the octagonal ceiling. The ceiling comprises eight trapezoidal stone panels around an octagonal capstone (Fig. 14). One might find it strange that this ceiling mandala is composed of texts instead of images. It calls to mind the bija mandala, or mandala composed of bija syllables (seed syllables in Sanskrit script, each symbolizing a deity), used in Japan since the eleventh century or earlier. ${ }^{44}$ As for the Baitayu Pagoda, however, the mandala used Chinese characters instead of bija syllables. The Baitayu Pagoda mandala even includes long modifiers explaining the deities in the mandala.

In the textual mandala at Baitayu Pagoda, besides the names of the nine deities forming the basic Uṣnissavijaya Dhäraṇi Mandala, more elements were added. The inscriptions on the eight trapezoidal panels are divided into upper and lower sections with a horizontal double-line in the middle of each panel. Each panel includes one of the eight bodhisattva names in its upper section. They are arranged in a clockwise direction, ${ }^{45}$ and the first one, in the southeast, reads:

did not think that the depository's ceiling formed a mandala. Chen Shushi 陳術石 and Tong Qiang 佟強, “Xingcheng Baitayuta digong mingke yu Liao dai wanqi fojiao xinyang” 興城白塔峪塔地宮銘刻與遼代晚期佛教信仰, Liao Jin lishi yu kaogu 遼金曆史與考古, no. 4 (2013): 219-242. Sǒng Sǒyǒng examined the ceiling as an example of the Eight Great Bodhisattvas Mandala from Liao, and suggested that Sixiao's thoughts may have been reflected in the inscriptions in Baitayu Pagoda's relic depository. However, instead of Huayan and Pure Land Buddhism relfected, in this mandala, Sorng focuses on the possible relationship between the mandala and the bodhisattva precepts (pusa jie 菩薩戒). Sǒng, "Liao dai bada pusa zaoxiang yanjiu," $85-86,97-98$, and 102-108. 저자앞: reflected 가 아닌지요?

43 For a transcript of all of the inscriptions, see Chen and and Tong, "Xingcheng Baitayuta digong mingke," 234-242.

44 These mandalas, also known as shüji mandara 種子曼茶羅, have some degree of similarity to the ceiling mandala of Baitayu mandala.

45 Chen Shushi and Tong Qiang wrote that the panels constituting the ceiling are arranged counter-clockwise, but the photograph of the ceiling shows that they are arranged in a clockwise manner. This is because the north and south are overturned when carving on the ceiling as opposed to the ground. See the directions marked in Figure 14 of this paper. 


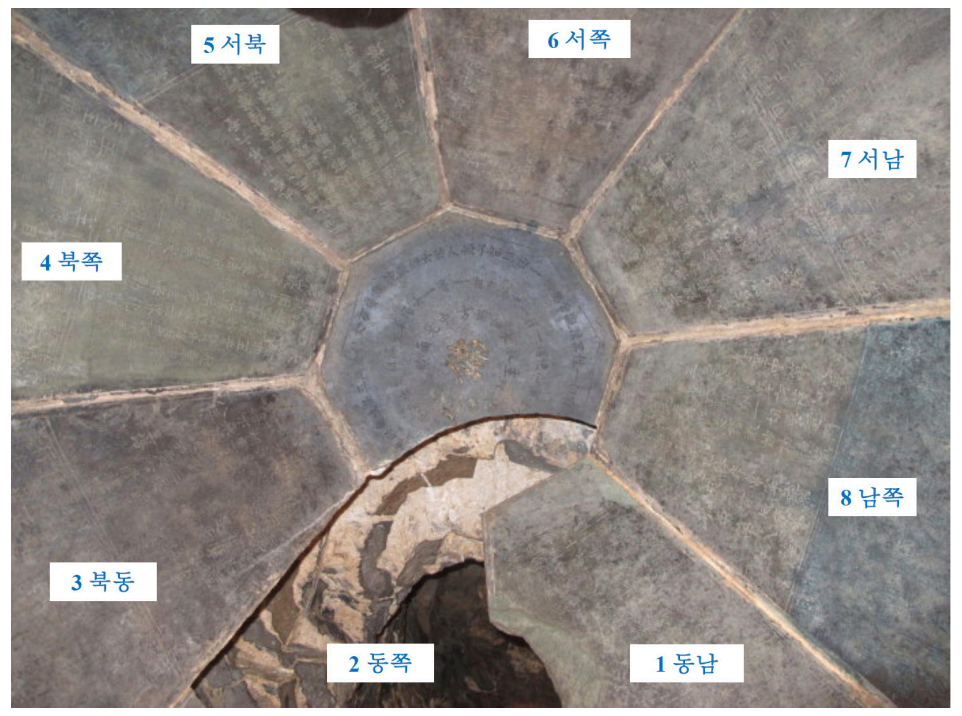

Fig. 14. Ceiling of the relic depository. Baitayu Pagoda, Xingcheng, Liaoning Province. Liao dynasty, 1092. (The north, south, east, and west appear transposed because the photograph captures the panels on the ceiling.)

The second sage among the nine sages: Horse-headed Bright King Great Bodhisattva Avalokiteśvara, who commiserates with sentient beings as if they were infants and always grants them peace and bliss ... The pagoda at the palace of King Śuddhodana [where the Buddha] was born ... [The first pagoda among the eight]. ${ }^{46}$

The names of the subsequent Eight Great Bodhisattvas are sequentially engraved in the corresponding trapezoidal ceiling panels. The “nine sages (juisheng 九聖)” in the inscription cited above indicates the Eight Great Bodhisattvas and Vairocana Buddha. Avalokiteśvara, the first bodhisattva of the mandala, is called the "second sage," because the first sage is Vairocana Buddha. Vairocana Buddha is embodied by the central Chinese character in the capstone. Inscribed in the center of the octagonal capstone is an sinograph $f_{0}$ 佛, meaning a Buddha. The character is much larger than other characters engraved on the ceiling, and traces of gold show that this central character was gilded. Three rings of inscribed sentences encircle this special "Buddha" presented in a sinograph form. The innermost ring

46 九聖中第二聖 馬頭明王 觀世音菩薩摩訶薩憐慜眾生如赤子 於一切時施安樂。。淨飯王宫生處塔。。。八塔中第一塔。 Transcription by Chen Shushi and Tong Qiang. Translation and bolding by the present author. The last six sinographs had been damaged, but Chen and Tong inferred the lost sinographs based on the same pattern being repeated in the other trapezoidal panels. 
states, "Veneration to Vairocana, my main object of veneration, the great preacher of yoga, in the center" (南無中方瑜珈大教主我本尊毗盧遮那). This verse encircling the central sinograph fo clearly suggests that the sinograph signifies not a generic Buddha but Vairocana Buddha.

Therefore the ceiling, with the capstone embodying Vairocana Buddha and the eight trapezoidal panels inscribed with the names of the Eight Great Bodhisattvas, together constitute a textual Ușnịșavijayā Dhāraṇi Mandala. The capstone's second ring of text, encircling the central sinograph, further suggests that the ceiling was designed as a mandala. Citing a verse from Hymn of One Hundred and Fifty Eulogies for Buddhas, ${ }^{47}$ four lines of scripture are inscribed. On the capstone, however, these lines are given a title, Gäthà of the Mandala (mantuojie 曼荼偈), meaning “verse of the mandala," as if they comprised an independent verse that had been composed for a mandala. ${ }^{48}$ As the passage was cited from a longer verse, this title was clearly given by the Liao monks who built the Baitayu Pagoda. The verse relates the healing and saving of afflicted sentient beings. It was likely inscribed on the capstone to eulogize the efficacy of the mandala, and suggests that the ceiling was designed as a mandala.

The entire Ușnịsavijaya dhāraṇi inscribed on the southwest wall of the relic depository further suggests that the mandala functioned to enact the power of this incantation. But it was not this mandala's only function, as explained below. ${ }^{49}$ This textual mandala in Baitayu Pagoda is important for understanding the evolution of the Ușnișavijaya Dhäraṇi Mandala in Liao Buddhism of the late eleventh century. Unlike the mandalas at Chaoyang North and Yingxian Timber Pagodas that followed the two scriptures from the Tang dynasty in terms of the deities encompassed in them, the Baitayu Pagoda mandala incorporates deities not mentioned in those scriptures. Moreover, it adopts elements from both esoteric and exoteric Buddhist traditions, even though a mandala is essentially a ritual apparatus for esoteric Buddhism.

First, the Baitayu Pagoda mandala ties the Eight Great Bodhisattvas to the bright kings (mingwang 明王, Sk. vidiyārāja) of esoteric Buddhism. Bright kings are fierce deities who manifest wrath against evil spirits in esoteric Buddhism. In the inscription of the southeast trapezoidal panel, cited above, the name of Avalokiteśvara (the first of the Eight Great Bodhisattvas), is combined with the name for Horseheaded Bright King (Matou mingwang 馬頭明王) as if the two were one deity. In the subsequent trapezoidal panels, each bodhisattva is combined with a particular bright king. For example, Vajrapāni bodhisattva is combined with Bright King of Conqueror of the Three Worlds (Xiangsanshi mingwang 降三世明王, also known as Trailokyavijaya); Mañjuśrī bodhisattva is linked with Bright King of Destroyer of Death (Daweide mingwang 大威德明王, also known as Yamāntaka); and Sarvanivaranavișkambhin bodhisattva is linked with Bright King of Immovable Worthy Sage (Budong zun mingwang 不動尊明王, also known as Acala). The scriptural basis of such connections was

47 The entire inscription of the second ring reads 曼茶偈云一毫一相充法界一行一德遍心源清淨廣大喻芳池能療眾生煩惱渴. It came from the scripture Hymn of One Hundred and Fifty Eulogy for Buddhas (Yibai wushi zan fo song 一百五十讚佛頌, T. 32, no. 1680:762a9-10) translated by Yijing義淨 (635-713). Chen and Tong, “Xingcheng Baitayuta digong mingke," 241n162.

48 The term mantu is an abbreviation of mantuluo 曼荼羅, or mandala.

49 The relic depository's overall relationship with the Ușnīṣavijayā dhāraṇi ritual will be discussed in a separate paper I am preparing. 


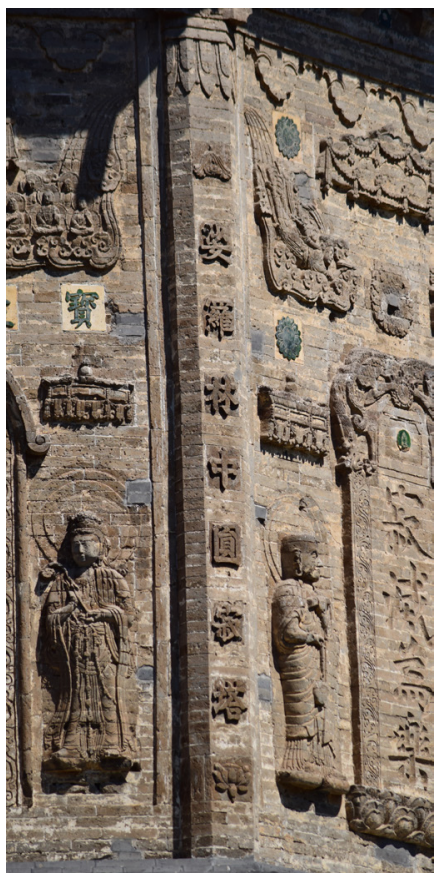

Fig. 15. A name of the Eight Great Pagodas inscribed on the pillar between the south wall and southwestern wall, Baitayu Pagoda. Liao dynasty, 1092. Xingcheng, Liaoning Province. [Photograph by Youn-mi Kim, 2014] probably the Sutra of Great and Marvelous Vajra Great Amrta Kund̦dali Yama Balze Uṣnisa. In it, each of the Eight Great Bodhisattvas manifests one of the Eight Great Vajra Bright Kings (bada jingang mingwang 八大金剛明王). ${ }^{50}$ The names of the bright kings in this scripture are almost identical to those of the Liao mandala engraved on the ceiling.

Second, the Eight Great Bodhisattvas are tied with the Eight Great Spiritual Pagodas (bada lingta 八大靈塔) in the mandala. The latter are the eight pagodas marking the Eight Great Sacred Placed (bada shengdi 八大聖地, Sk. aștamahāsthāna) in India. Relief images of the Eight Great Spiritual Pagodas and their inscribed names frequently appeared on the exterior of Liao pagodas since the mid-eleventh century. ${ }^{51}$ This textual mandala reflects the tendency towards textualization observed in the exterior and interior of Baitayu Pagoda. The exterior also bears the names of the Eight Great Spiritual Pagodas on the eight corner pillars of the ground story (Fig. 15). Conforming to the tendency towards textualization exhibited in the mandala inside the pagoda, the Eight Great Spiritual Pagodas on the exterior were also created using text instead of images. In the Baitayu Pagoda mandala, these eight pagodas are sequentially featured in the eight trapezoidal panels with the eight bodhisattvas. For example, the southeast ceiling panel for the first bodhisattva Avalokiteśvara reads, "the pagoda at the palace of King Śuddhodana [where the Buddha] was born," which is the first of the Eight Great Spiritual Pagodas.

The remaining panels connect each subsequent bodhisattva with a respective pagoda. The mandala at Baitayu Pagoda clarifies that the two most distinctive iconographic elements of Liao pagodas were closely related to each other in Liao Buddhism. ${ }^{52}$

50 Chen and Tong, “Xingcheng Baitayuta digong mingke," 230-231. For a relevant passage in the sutra, see 大妙金剛 大甘露軍拏利焰倀熾盛佛頂經 Damiao jingang daganlu junnali yanman chisheng foding jing, T. 19, no. 965: 340c13-341a19.

51 For the Eight Great Spiritual Pagodas in Liao, see Youn-mi Kim, "Virtual Pilgrimage and Virtual Geography: Power of Liao Miniature Pagodas (907-1125),” Religions 8, no. 10 (October, 2017): 1-29; Sŏng Sǒyǒng 成敘永, “Jingangjie mantuluo yu xinde bada lingta xinyang de ronghe: Chaoyangbeita tashen fudiao yanjiu” 金剛界曼茶羅與新的八大靈塔信仰的融合: 朝陽北塔塔身浮雕研究, Gugong bowuyuan yuankan 故宮博物院院刊 190, no. 2 (2017): 96-11; and Chu Kyŏngmi (Joo Kyeongmi) 주경미, “Yodae p'altae yŏngt'ap tosang ǔi yŏn'gu” 遼代 八大靈塔 圖像의 研究, Chungang Asia yŏn'gu 중앙아시아연구 14 (2009): 141-167.

52 Daming Pagoda in present-day Ningcheng County, Chifeng, in Inner Mongolia shows that these modifications observed in the mandala at Baitayu Pagoda were probably shared throughout Liao in the late eleventh century. Vairocana Buddha, the Eight Great Bodhisattvas, the eight bright kings, and the Eight Great Spiritual Pagodas all intermingle on the exterior of Daming 
Third, the mandala adopts Huayan Buddhist deities and teaching, even though a mandala is essentially a feature of esoteric Buddhism. The third and outermost ring of inscription on the capstone cites verses from the Flower Garland Sutra. It reads:

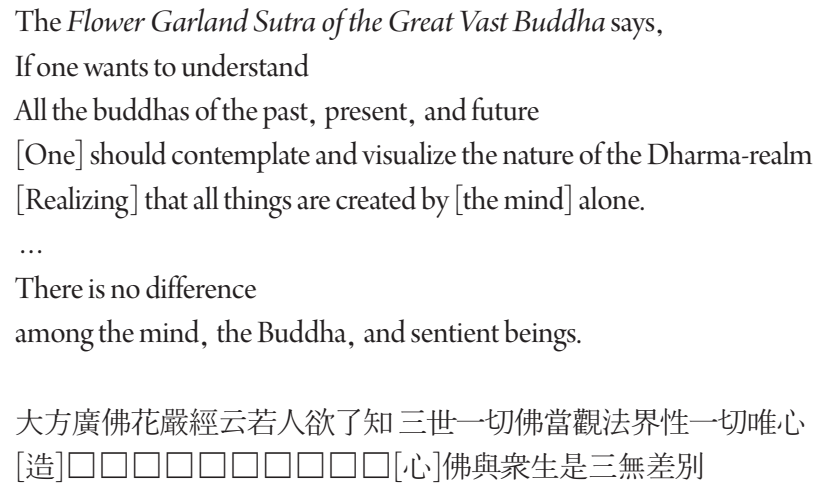

The inscription begins with the Four-line Verse of Huayan from the eighty-fascicle Flower Garland Sutra and ends with another famous verse from the sixty-fascicle Flower Garland Sutra. ${ }^{53}$ It seems that one more famous verse from the same scripture existed between the two, but it has been lost due to the damage on the ceiling. Besides these verses from the most important scripture of Huayan Buddhism, the lower half of the eight trapezoidal panels, comprising the outer realm of the octagonal mandala, are primarily engraved with One Hundred and Twenty Benevolent Sages of Huayan Buddhism. As Chen Shushi and Tong Qiang have noted, the worship of these 120 sages, selected from the Flower Garland Sutra, is unique to Liao Buddhism. Several Liao monasteries, including the main Buddha hall at Fengguo Monastery 奉國寺 in Yixan, Liaoning Province, originally had images of these 120 sages of Huayan Buddhism. ${ }^{54}$ Scholars largely agree that the most distinctive feature of Liao Buddhism is its synthesis of Huayan teaching with esoteric practices. ${ }^{55}$ Reflecting this larger trend in Liao Buddhism, even the esoteric

Pagoda through the reliefs and inscriptions adorning the pagoda's ground story.

53 The inscription replaces the letters hua 華, ying 應, and $j i$ 及 in the scriptures with the characters hua 花, dang 當, and $y u$ 與, respectively; however, this does not change the meaning of the phrases. The two verses come from different versions of the Flower Garland Sutra. For the two verses in their original form, see Dafangguang fo huayan jing, T. 10, no. 279: 102a-b; and T. 9, no. 278: 465c29.

54 Chen and Tong, "Xingcheng Baitayuta digong mingke," 228-229, 240-241.

55 For the synthesis of Huayan and Esoteric Buddhism in Liao, see Wakiya Kiken 脇谷撝謙, "Ryō Kin jidai no bukkyō" 遼金時代の佛教, Rokujō gakuhō 六條學報 126 (1912): 31-43; Wakiya Kiken, “Ryō-Kin bukkyō no chūshin” 遼金佛教の 中心, Rokujō gakuhō 135 (1913); 2-9; and “Ryō dai no mikkyō” 遼代の密教, Wu jin deng 無盡燈 (1912); Kamata Shigeo 鎌田茂雄, Chūgoku kegon shisō no kenkyū 中國華嚴思想の研究 (Tokyo: Tōkyo daigaku shuppankai, 1965), 604-618; Robert M. Gimello, “Wu-t’ai Shan 五臺山 during the Early Chin Dynasty 金朝: The Testimony of Chu Pien 朱弁,” Zhonghua foxue xuebao 中華佛學學報 7 (1994): 501-612; and Henrik Sørensen, “Esoteric Buddhism under the Liao," Esoteric Buddhism and the Tantras in East Asia, ed. Charles Orzech, Henrik Sørensen and Richard Payne (Leiden and Boston: Brill, 2011), 459-461. 
Buddhist mandala came to mingle with Huayan Buddhism in the late Liao period as reflected in the mandala at Baitayu Pagoda.

Lastly, but most importantly, the mandala fuses esoteric Buddhism with Pure Land Buddhism. The lower portions of the trapezoidal panels are inscribed with the twelve different names of Amitäbha Buddha, as well as the Buddhas of the Five Directions from esoteric Buddhism, and the Seven Buddhas of the Past. Why were the twelve names of Amitābha Buddha, perhaps the most distinctive feature of Baitayu Pagoda's mandala, included in this mandala? It is probably because the mandala was prepared for a good rebirth for the monks who had commissioned the pagoda and their teachers. As a matter of fact, Baitayu Pagoda, which enshrines the mandala, was erected to pray for the monks' rebirth in the Pure Land, as proven by the pagoda's dedicatory inscription on its relic depository's south wall (Fig. 16). ${ }^{56}$ This dedication informs us that the pagoda was built by monks, and for monks: its patrons were the monks of Haiyunsi 海雲寺 in the nearby Juehua Island 覺花島; ${ }^{57}$ and the pagoda was built to wish for their rebirth in the Pure Land and attainment of awakening. The dedicatory inscription includes three prayers for the pagoda's patrons, among which the second is the most important for our discussion. The first one that prays for the longevity of the emperor and imperial family and the welfare of officials is almost a cliché, as it commonly appears in dedicatory inscriptions of Buddhist monuments. The second

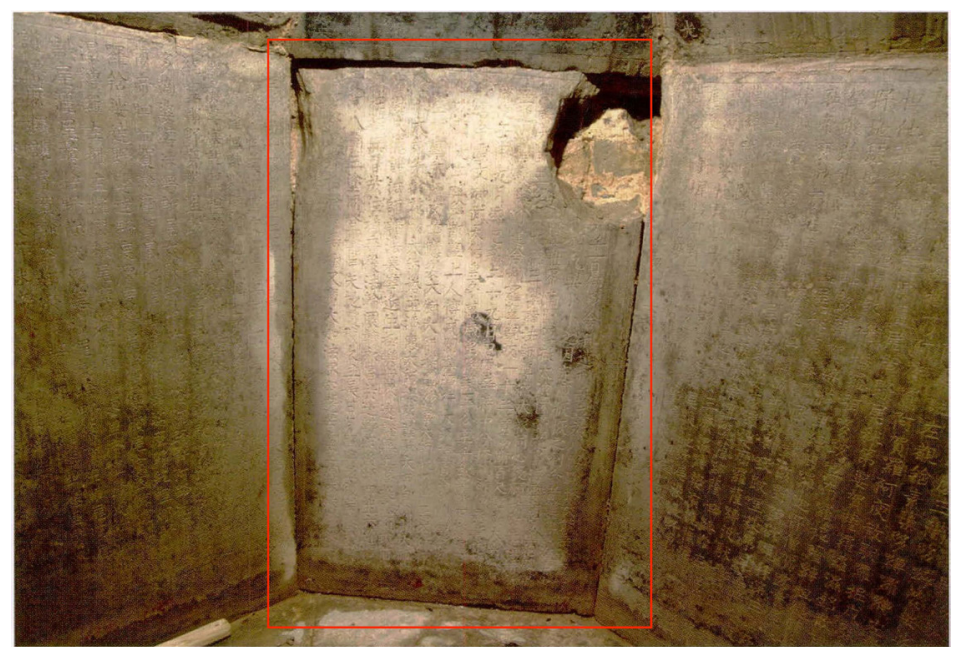

Fig. 16. Dedicatory inscription on the relic depository's south wall. Baitayu Pagoda, Xingcheng, Liaoning Province. Liao dynasty, 1092 [Image adapted from Chen and Tong, "Xingcheng Baitayuta digong mingke," plate 4]

56 For a transcription of the dedicatory inscriptions, see Chen and Tong, "Xingcheng Baitayuta digong mingke," 234.

57 The character hua 花 in the island's name actually refers to the character hua 華, which is a character in the name Huayan 華嚴 Buddhism. The two characters were sometimes interchangeable, and the inscriptions in Baitayu Pagoda's relic depository's ceiling also use hua 花 instead of hua 華 in writing the title of Flower Garland Sutra (as 大方廣佛花嚴經). 
is more unique and offers information useful for our discussion. It mentions particular monks, including the eminent Liao monk Sixiao at Haiyunsi, and prays that they will "be reborn in the Pure Land in their near afterlife and attain supreme awakening in the further afterlife” (近生極樂世界遠證無上菩提). ${ }^{58}$ It is notable that these monks built this pagoda in preparation for their afterlife, wishing to reborn in the Pure Land of Amitābha Buddha. ${ }^{59}$

There is one more fact suggesting that the primary function of the pagoda and its mandala was to prepare for the monks' rebirth in the Pure Land: the pagoda's location. Baitayu Pagoda was erected on the mountain that served as a necropolis for the monks of Haiyunsi. Although the Liao monastery that hosted the pagoda has not survived, a stone stele that was originally enshrined in the pagoda's relic depository records that Baitayu Pagoda was built at Wuji Hall 悟寂院 on Mount Gongtong 空通山. ${ }^{60}$ The aforementioned dedication records that Wuji Hall on Mount Gongtong is "the tomb site of the predecessors” (先祖墳所) (Fig. 16). ${ }^{61}$ Wuji Hall was a sub-temple of Haiyunsi 海雲寺, and the "predecessors" in this context were the deceased monks of Haiyunsi. According to Zhu Zifang 朱子方, quite a few stone coffins and brick panels inscribed with monks' names were excavated in the vicinity of Baitayu Pagoda, suggesting that Wuji Hall was part of a larger monastery that managed the tombs of Haiyunsi monks. ${ }^{62}$

Although Pure Land Buddhism and esoteric Buddhism might seem like very different kinds of Buddhist traditions, the praying for the rebirth in Pure Land Buddhism harmonizes well with the

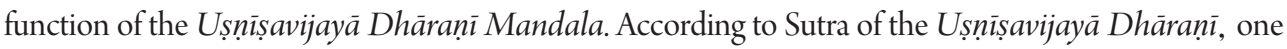
of the dhäraniı s primary functions is to obtain good afterlife. In the sutra, the Buddha helps a minor god named Shanzhu 善住 avoid his predetermined miserable reincarnations - which included falling into hell and rebirth as a blind person - through the efficacy of the Ușnịsavijayā dhärañī. ${ }^{63}$ By adding the names of Amitābha Buddha, who leads the deceased to his pure land, the Liao mandala offered double insurance to its patrons and beneficiaries, guaranteeing both salvation from hell and rebirth in the Pure Land. Furthermore, the twelve names of Amitābha have a connection with Amoghavajra's esoteric Buddhism as well, because they appear not only in the Larger Sukhāvatīvyūha ${ }^{64}$ but also in the Dhäraṇi Scripture of Collected Amitäbha Samädhi of the Nine Grades Rebirth, which was translated by Amoghavajra. ${ }^{65}$

58 For a complete transcription of the dedicatory inscriptions from this relic deposit, see Chen and Tong, "Xingcheng Baitayuta digong mingke," 234.

59 The last prayer in Baitayu Pagoda's dedicatory inscription is a more general prayer for monks and thus does not mention particular figures.

60 For a transcription of this stele inscription, see Nan Xiang 南郈, Liao dai shike wenbian 遼代石刻文編 (Shijiazhuang: Hebei jiaoyu chubanshe, 1995), 451.

61 For a transcription of this dedication inscription, see Chen and Tong, "Xingcheng Baitayuta digong mingke," 234.

62 Zhu Zifang 朱子方, “Ba Xingcheng Tazigou chutu de liangjian shike” 跋興城塔子溝出土的兩件石刻, Liao Jin Qidan Nüzhen shi yanjiu dongtai 遼金契丹女真史研究動態 no. 2 (1984): 1 .

63 Foding zunsheng tuoluoni jing, T. 19, no. 967.

64 Fo shuo Wuliangshou jing 佛説無量壽經, T. 12, no. 360: 270a-b.

65 Jiupin wangsheng Amituo sanmodi ji tuoluoni jing 九品往生阿彌陀三摩地集陀羅尼經, T.19, no. 933: 79c11-15. It was Chen 
Now let us examine the relationship between Baitayu Pagoda and the Liao monk Sixiao. Sixiao was revered for his deep understanding of Buddhist teaching by Emperors Xingzong 興宗 (r. 1031-1055) and Daozong 道宗(r.1055-1101). ${ }^{66}$ Haiyunsi on Juehua Island had a close connection with the Liao imperial family, and Sixiao had served as abbot of this monastery. ${ }^{67}$ The aforementioned pagoda's dedicatory inscription suggests that Sixiao was perhaps one of the most important monks for whom the pagoda was built. The dedication prays for rebirth in the Pure Land and the attainment of awakening for a dozen different monks. In this list, Sixiao's name is at the beginning, preceded only by an elderly monk who had already passed away. ${ }^{68}$ As Sixiao was a monk of Haiyunsi, he had been or would be buried in the necropolis near the pagoda, and the pagoda's relic depository was engraved with the Uṣnișavijayā Dhāraṇi Mandala.

Here, it is notable that the monk Sixiao had written a two-fascicle commentary and one-fascicle analytic exegesis (kewen 科文) on the Sutra of the Eight Great Bodhisattvas Mandala. ${ }^{69}$ Although these writings have been lost and their contents forgotten, they must have included Sixiao's understanding and analysis of the Eight Great Bodhisattvas Mandala. Considering the Liao Buddhist tradition, in which all the surviving Eight Great Bodhisattvas Mandalas have Vairocana Buddha in the center, the mandala he discussed in his writings was probably the Ușnịșavijayā Dhāraṇi Mandala. The Ușnịșavijayā Dhāraṇi Mandala prepared for his afterlife likely shares commonalities with his understanding of the mandala. This Liao mandala from Baitayu Pagoda featured a level of complexity unprecedented in previous Liao Uș̣niṣavijayā Dhāraṇi Mandalas. The new addition of the twelve names of Amitābha Buddha and the One Hundred and Twenty Benevolent Sages of Huayan Buddhism may have originated from the monk's new interpretation of the mandala. Although his exegesis and commentary have been lost, we can deduce that he probably discussed the mandala's relationship to Amitābha Buddhas, the Hauyan Sages, bright kings, and the Eight Great Spiritual Pagodas in his writings.

Before ending this paper, it is necessary to briefly mention the uniqueness of the Baitayu Pagoda. As mentioned above, it shares some similarities with the bija mandala, which was one of the four types of mandalas of the Shingon school. At the same time, the Liao mandala was fundamentally different from the latter, as it used Chinese sinographs instead of bija syllables and even included verse and prose. At the

and Tong who first found the twelve names in this dhäraṇi sutra. Chen and Tong, "Xingcheng Baitayuta digong mingke," 292 230 .

66 For more on this monk, see Kamio Kazuharu 神尾式春, Kittan Bukkyō bunkashi kō 契丹仏教文化史考 (Dairen shi: Manshū bunka kyōkai, 1937), 39, 198-199; and You Li 尤李, “Liao dai gaoseng Sixiao yu Juehuadao” 遼代高僧思孝與覺華島, Zhongyang minzu daxue xuebao: Zhexue shehui kexue ban 中央民族大學學報-哲學社會科學版 39, no. 1 (2012): 47-51.

67 Sŏng, Sŏyŏng also pointed out the importance of this monk in Baitayu Pagoda. Sŏng, "Liao dai bada pusa zaoxiang yanjiu," 81109.

68 Chen Shushi and Tong Qiang identified in their 2013 article that “撰百本科制四部疏守司空輔國大師” in the inscription refers to the monk Sixiao. Chen and Tong, "Xingcheng Baitayuta digong mingke," 221-222.

69 The titles of these texts were recorded in the monk Ǔich'ǒn's catalogue compiled in Koryǒ. Sinp'yŏn chejong kyojang ch'ongnok, T. 55, no. 2184: 1172c28-29. This catalogue informs us that one more Liao monk named Zhishi 志實 had written a commentary on the same scripture, which testifies to the importance of Sutra of the Eight Great Bodhisattvas Mandala in Liao Buddhism. 
same time, the earlier Liao-period mandalas examined above- the two-dimensional example from Chaoyang North Pagoda and the sculptural one from Yingxian Timber Pagoda—each reminds us of the two other types of Shingon mandalas in Japan. The former can be categorized as the great mandala, on which the figures of Buddhas and bodhisattvas are painted, and the latter as the karma mandala, which embodies Buddhas and deities in sculptural form. The four types of mandala in Japan originate from the Shingon school founded by Kūkai 空海 (774-835), who studied in Tang China. The Liao mandalas made in various formats may have originated from the Tang tradition, but their difference from the Japanese examples also reflects innovations and modifications during the Liao dynasty. ${ }^{70}$ This suggests that Liao constitutes a major branch of esoteric Buddhist tradition, comparable to the Shingon school in Japan, after the fall of the Tang.

\section{Conclusion}

This paper examined three representative Uṣnișavijayā Dhāraṇi Mandalas in Liao pagodas. In the mid-eleventh century, as exemplified in the mandalas from Chaoyang North Pagoda and Yingxian Timber Pagoda, the Ușnịșavijayā Dhāraṇi Mandala were designed based on the Tang dynasty ritual manual and sutra translated by Amoghavajra. At the same time, these mandalas, as well as the Ușnịṣavijayā Dhärañi Mandala at the Daming Pagoda from the late $11^{\text {th }}$ century, share details not bound to the Tang scriptures. Their mostly matching arm positions suggest that they shared a visual model for the Ușnịșavijayā Dhāraṇi Mandala that was developed and circulated in Liao. In addition, it is notable that these Ușnịșavijayā Dhäraṇi Mandalas from Liao were all made in different formats. Chaoyang North Pagoda's was made in two-dimensional form on gold plate, Yingxian Timber Pagoda's in three-dimensional form using wood and clay, and Daming Pagoda's in relief on the pagoda's exterior. Their locations also varied, ranging from Liaoning and Shanxi Provinces to Inner Mongolia. Despite such differences of medium and region, they shared the same model and show similarities even in such details as the bodhisattvas' arm positions.

By the late eleventh century, however, the Ușnișavijayā Dhāraṇi Mandala had evolved into a more complicated form in Liao, combining more deities not only from esoteric Buddhism but also from Huayan and even Pure Land Buddhism. The textual mandala engraved on the ceiling of Baitayu Pagoda aptly exemplifies Liao modification of the Ușnịșavijayā Dhäraṇi Mandala. Since Baitayu Pagoda was built for the rebirth of the eminent Liao monk Sixiao, the contents of its Uṣnișavijayā Dhāraṇi Mandala help us infer, though only partially, the contents of Sixiao's lost commentary and exegesis on Sutra of the Eight Great Bodhisattvas Mandala, in which he probably discussed the Uș̣ișavijayā Dhäraṇi Mandalas (i.e., Eight Great Bodhisattvas Mandala with Viarocana Buddha in the center). As Sixiao was

70 I am grateful to the anonymous reviewer who pointed out the similarity between the Liao mandalas and the four types of Japanese of mandala. 
one of the most erudite monks in Liao, whose writings were circulated in neighboring lands, including the Koryŏ, it is difficult to imagine that his writings on the mandala had no influence on the mandala featured at Baitayu built for him. This modified Uṣnịṣavijayā Dhāraṇi Mandala appears to have circulated widely in late-eleventh-century Liao as the deities newly added in this mandala were also featured in Daming Pagoda's mandala. All of these factors suggest that the Ușnịșavijayā dhäraṇi played an important role in Liao Buddhism and contributed to the development of mandalas and pagoda architecture unique to the Liao empire.

* Keywords: Liao Buddhism, Ușnịșavijayā dhāraṇi, mandala, Eight Great Bodhisattvas, Pagoda, Sixiao, Huayan, Pure Land, esoteric Buddhism, Yingxian Timber Pagoda, Chaoyang North Pagoda, Baitayu Pagoda

|투고일 2020년 6월 20일 | 심사개시일 2020년 6월 26일| 심사완료일 2020년 8월 7일 | 


\section{References}

\section{Historical records}

Bada pusa mantuoluo jing 八大菩薩曼茶羅經, T.20, no. 1167.

Dafangguangfo huayan jing 大方廣佛華嚴經, T.9, no.278; and T. 10, no. 279.

Damiao jingang daganlu junnali yanman chisheng foding jing 大妙金剛大甘露軍拏利焰鬘熾盛佛頂經, T. 19, no. 965.

Foding zunsheng tuoluoni jing 佛頂尊勝院羅尼經, T. 19, no.967.

Foding zunsheng tuoluoni niansong yigui fa 佛頂尊勝院羅尼念誦儀軌法, T. 19, no. 972.

Fo shuo Wuliangshou jing 佛説無量壽經, T. 12, no. 360.

Jiupin wangsheng Amituo sanmodi ji tuoluoni jing 九品往生阿彌陀三摩地集陀羅尼經, T.19, no.933.

Sinp'yön chejong kyojang ch'ongnok 新編諸宗教藏總錄, T.55, no. 2184.

Yibai wushi zan fo song一百五十讚佛頌, T.32, no. 1680.

\section{Secondary sources in Western and East Asian Languages}

\section{English}

Banerjee, Radha. Ashtamahabodhisattva: The Eight Great Bodhisattvas in Art and Literature. New Delhi: Abha Prakashan, 1994.

Barrett, T.H. "Stūpa, Sūtra, and Sarīra in China, C.656-706," Buddhist Studies Review 18, no.1(2001): 1-64.

Bimal, Bandyopadhyay. Buddhist Centres of Orissa: Lalitagiri, Ratnagiri, and Udayagiri. Sundeep Prakashan, 2004.

Copp, Paul F. "Voice, Dust, Shadow, Stone: The Makings of Spells in Medieval Chinese Buddhism," PhD dissertation. Princeton University, 2005.

The Body Incantatory: Spells and the Ritual Imagination in Medieval Chinese Buddhism. New York: Columbia University Press, 2014.

Forte, Antonino. "The Preface to the So-Called Buddhapālita Chinese Version of the Buddhosṇina Vijaya Dhāraṇi Sūtra” unpublished paper.

Gimello, Robert M. “Wu-t'ai Shan 五臺山 during the Early Chin Dynasty 金朝: The Testimony of Chu Pien 朱弁,” Zhonghua foxue xuebao 中華佛學學報第7 (1994): 501-612.

Hock, Nancy. "Buddhist Ideology and the Sculpture of Ratnagiri, Seventh through Thirteenth Centuries." PhD Dissertation, University of California-Berkeley, 2005.

Jinhua, Chen. "Śarira and Scepter: Empress Wu's Political Use of Buddhist Relics," Journal of the International Association of Buddhist Studies 25. no. 1-2. (2003): 33-150.

Kim, Youn-mi. "Virtual Pilgrimage and Virtual Geography: Power of Liao Miniature Pagodas (907-1125).” Religions 8, no. 10 (October, 2017): 1-29.

"The Hidden Link: Tracing Liao Buddhism in Shingon Ritual." Journal of Song-Yuan Studies 43, Special Issue on the Liao Dynasty (2013, published in 2015): 117-170. 
“Eternal Ritual in an Infinite Cosmos: The Chaoyang North Pagoda (1043-1044).” PhD Dissertation Harvard University, 2004.

Lin, Wei-Cheng. "Performing Center in a Vertical Rise: Multilevel Pagodas in China's Middle Period." Ars Orientalis 46 (2016): 100-134.

Malandra, Geri Hockfield. Unfolding a Mandala: The Buddhist Cave Temples at Ellora. New York: State University of New York Press, 1993.

Pal, Pratapaditya. "A Note on the Mandala of the Eight Bodhisattvas." Archives of Asian Art 26 (1972-1973): 71-73

Sørensen, Henrik. "Esoteric Buddhism under the Liao." In Esoteric Buddhism and the Tantras in East Asia, edited by Charles Orzech, Henrik Sørensen and Richard Payne, 456-464. Leiden and Boston: Brill, 2011.

Wang, Michelle C. The Visual Culture of Esoteric Buddhism at Dunhuang (Leiden and Boston: Brill, 2018).

\section{Korean Language}

Chu, Kyŏngmi (Kyeongmi Joo) 주경미. “Yodae p’altaeyŏngt’ap tosang ŭi yŏn'gu” 遼代 八大靈塔 圖像의 研究. Chungang Asia yŏn'gu 중앙아시아연구 14 (2009): 141-172.

Fujiwara, Takato. Kŏran pulgyosa yŏn'gu 거란 불교사 연구. Seoul: Ssiaial, 2020.

$\mathrm{Ku}$, Chin-gyŏng 구진경. “Koryǒ Chosǒn sidae Amit'a p'aldaebosaldo ǔi pigyo yŏn'gu” 고려 조선시대 아미타 팔대보살도 비교 연구. M.A. thesis, Dongguk University, 2004.

Mun, Myŏngdae 문명대. "Noyŏng ŭi Amit'a Chijang purhwa e taehan kochal” 노영의 아미타 지장불화에 대한 고찰. Misul charyo 미술자료 25 (1979): 47-57.

Yang, Hǔi-jŏng (Yang Heejung) 양희정. “Koryŏ sidae Amit'a p'altae posalto tosang yǒn'gu” 고려시대 아미타팔대보살도 도상 연구.Misul sahakyŏn'gu 美術史學研究 257 (2008): 67-103.

“Han'guk p'altae posal tosang yŏn'gu” 韓國八大菩薩 圖像研究, M.A. thesis (Seoul National University, 2006)

\section{Chinese Language}

Chen, Mingda 陳明達. Yingxian muta 應縣木塔. Beijing: Wenwu chubanshe, 1966.

Chen, Shushi 陳術石 and Tong Qiang 佟強. “Xingcheng Baitayuta digong mingke yu Liao dai wanqi fojiao xinyang” 興城白塔峪塔地宮銘刻與遼代晚期佛教信仰. Liao Jin lishi yu kaogu 遼金曆史與考古, no. 4 (2013): 2236.

Li, Jingiie 李靜傑. “Shanbei Song Jin shiku Dari rulai tuxiang leixing fenxi” 陝北宋金石窟大日如來圖像類型分析. Gugong bowuyuan yuankan 故宮博物院院刊 167, no.3 (2013): 119-133.

Liaoning-sheng wenwu kaogu yanjiusuo 遼寧省文物考古研究所 and Chaoyang shi Beita bowuguan 朝陽市北塔博物館. Chaoyang Beita: Kaogu fajue yu weixiu gongcheng baogao 朝陽北塔: 考古發掘 與維修工程報告 (Beijing: Wenwu chubanshe, 2007).

Liu, Shufen 劉淑芬. “Jingchuang zhi xingzhi, xingzhi he laiyuan: jingchuang yanjiu zhi er” 經幢的形制、性質和來源 經幢研究之二. Zhongyang yanjiuyuan lishi yuyan yanjiusuo jikan 中央研究院歷史語言研究所集刊 68, no. 3 (1997): 643-786. 
Miezui yu duwang: Foding zunsheng tuoluoni jingchuang zhi yanjiu 滅罪與度亡: 佛頂尊勝陀羅尼經幢 之研究. Shanghai guji chubanshe, 2008.

Luo Zhao 羅炤. “Yingxian muta suxiang de zongjiao chongbi tixi” 應縣木塔塑像的宗教崇拜體系. Yishu shi yanjiu 藝術史研究 12 (2010): 189-216.

Nan Xiang 南绵. Liao dai shike wenbian 遼代石刻文編. Shijiazhuang : Hebei jiaoyu chubanshe, 1995.

Sŏng, Sǒyŏng 成敘永. “Liao dai bada pusa zaoxiang yanjiu” 遼代八大菩薩造像研究, Liao Jin lishi yu kaogu 遼金曆史與考古 7, no.1 (2017): 81-109.

"Jingangjie mantuluo yu xinde bada lingta xinyang de ronghe: Chaoyangbeita tashen fudiaoyanjiu" 金剛界曼荼羅與新的八大靈塔信仰的融合：朝陽北塔塔身浮雕研究. Gugong bowuyuan yuankan 故宮博物院院刊190, no. 2(2017): 96-111.

You, Li 尤李. “Liao dai gaoseng Sixiao yu Juehuadao” 遼代高僧思孝與覺華島. Zhongyang minzu daxue xuebao: Zhexue shehui kexue ban 中央民族大學學報-哲學社會科學版 39, no. 1 (2012): 47-57.

Yu, Bo 于博. “You bada lingta tuxiang guankui Liao dai fojiao xinyang” 由八大靈塔圖像管窺遼代佛教信仰. Dongbei shidi 東北史地, no.5 (2015):29-35.

Zhu, Zifang 朱子方. “Ba Xingcheng Tazigou chutu de liangjian shike” 跋兴城塔子沟出土的两件石刻. Liao Jin Qidan Nüzhen shi yanjiu dongtai 辽金契丹女真史研究动态, no. 2(1984).

\section{Japanese Language}

Chǒng, Ut’aek (Chung Woo-thak) 정우택. Kōrai jidai Amida gazō no kenkyū 高麗時代阿弥陀画像の研究. Kyōto: Nagata Bunshōdō, 1990.

Kamata, Shigeo 鎌田茂雄. Chūgoku kegon shisō no kenkyū 中國華嚴思想の研究. Tokyo: Tōkyo daigaku shuppankai, 1965.

Kamio, Kazuharu 神尾式春. Kittan Bukkyō bunkashi kō 契丹仏教文化史考. Dairen-shi: Manshū bunka kyōkai, 1937.

Matsunaga, Keiji 松長恵史. Indoneshia no Mikkyō インドネシアの密教. Kyōto: Hōzōkan, 1999.

Wakiya, Kiken 脇谷撝謙. “Ryō-Kin bukkyō no chūshin” 遼金佛教の中心. Rokujō gakuhō 135 (1913): 2-9

."Ryō Kin jidai no bukkyō” 遼金時代の佛教, Rokujō gakuhō六條學報 126 (1912):31-43.

“Ryō dai no mikkyō” 遼代の密教, Wu jin deng 無盡燈(1912). 


\section{Abstract}

This paper examined three representative Uș̣nișavijayā Dhāraṇi Mandalas in Liao pagodas. In the mid-eleventh century, as exemplified in the mandalas from Chaoyang North Pagoda and Yingxian Timber Pagoda, the Ușnịsavijayā Dhāraṇi Mandala were designed based on the Tang dynasty ritual manual and sutra translated by Amoghavajra. At the same time, these mandalas, as well as the Uṣnịṣavijaya Dhāraṇi Mandala at the Daming Pagoda from the late $11^{\text {th }}$ century, share details not bound to the Tang scriptures. Their mostly matching arm positions suggest that they shared a visual model for the Ușnịșavijayā Dhäraṇi Mandala that was developed and circulated in Liao. In addition, it is notable that these Uṣnịsavijayā Dhāraṇi Mandalas from Liao were all made in different formats. Chaoyang North Pagoda's was made in two-dimensional form on gold plate, Yingxian Timber Pagoda's in three-dimensional form using wood and clay, and Daming Pagoda's in relief on the pagoda's exterior. Their locations also varied, ranging from Liaoning and Shanxi Provinces to Inner Mongolia. Despite such differences of medium and region, they shared the same model and show similarities even in such details as the bodhisattvas' arm positions.

By the late eleventh century, however, the Uṣnịșavijayā Dhāraṇi Mandala had evolved into a more complicated form in Liao, combining more deities not only from esoteric Buddhism but also from Huayan and even Pure Land Buddhism. The textual mandala engraved on the ceiling of Baitayu Pagoda aptly exemplifies Liao modification of the Uṣnịșavijayā Dhāraṇi Mandala. Since Baitayu Pagoda was built for the rebirth of the eminent Liao monk Sixiao, the contents of its Ușnịsavijayā Dhäranī Mandala help us infer, though only partially, the contents of Sixiao's lost commentary and exegesis in which he probably discussed the Uṣnịsavijayā Dhāraṇī Mandalas (i.e., Eight Great Bodhisattvas Mandala with Viarocana Buddha in the center). As Sixiao was one of the most erudite monks in Liao, whose writings were circulated in neighboring lands, including the Koryŏ, it is difficult to imagine that his writings on the mandala had no influence on the mandala prepare for his afterlife at Baitayu Pagoda. This modified Uṣnịsavijayā Dhāraṇi Mandala appears to have circulated widely in late-eleventh-century Liao as the deities newly added in this mandala were also featured in Daming Pagoda's mandala. All of these factors suggest that the Ușnissavijayā Dhäraṇi played an important role in Liao Buddhism and contributed to the development of mandalas and pagoda architecture unique to the Liao empire. 